\title{
Herbicides and the Risk of Neurodegenerative Disease
}

\author{
Krithika Muthukumaran, Alyson J. Laframboise \\ and Siyaram Pandey \\ University of Windsor \\ Canada
}

\section{Introduction}

In the quest for increased agricultural productivity, longer shelf life of produce, weed-free lawns and sanitized facilities, we have developed a plethora of pesticides. Pesticides are a broad range of substances commonly used to control insects, weeds, and fungi (plant diseases). They are classified by target organism or mode of use as insecticides, herbicides, fungicides, or fumigants. Development, manufacturing and large scale application of these products have become main stream practices in industry, agriculture and domestic sectors. More than 18,000 products are registered for use in the United States, and $>1$ billion pounds of pesticides are applied annually as of 2007 (EPA, 2011). Any chemical designed to kill weeds or insects certainly has potential to harm humans. Short term exposures to low dosages of these chemicals are generally non-toxic. Detoxification systems in the human body are capable of modifying and clearing these molecules from the system efficiently. However, long term exposure to these toxic chemicals combined with poor drug catabolizing cytochrome p450 activity in some individual could lead to its accumulation in the system and toxicity leading to increased risk of certain diseases. Many of the herbicides are toxic to mitochondria and cause oxidative stress. Neuronal cells, being critically dependent on mitochondrial function and sensitive to oxidative stress, often fall victim to these herbicides. Slow and progressive loss of neurons leads to neurodegenerative diseases. In this review we describe toxic effects, mechanism of action and results of animal studies of selected herbicides implicated in neurodegenerative diseases. We also discuss the need for stringent testing of these kinds of substances for neurotoxicity and recent advances in neuroprotective therapies as outlined in the overview before.

\section{Specific herbicides with neurodegenerative effects}

\subsection{Paraquat}

\subsubsection{Background and history of use}

Paraquat is the trade name of $\mathrm{N}, \mathrm{N}^{\prime}$-dimethyl-4,4'-bipyridinium chloride, the dichloride salt of the radical 1,1'-dimethyl-4,4'-dipyridilium. It is one of the most commonly used and powerful herbicides and was synthesised in 1932 at the Rockefeller Institute by Michaelis 
(Michaelis \& Hill, 1933). In the early years it was called methyl viologen because it readily reduced to a stable blue or violet free radical and this property was exploited by biochemists who used the compound as an oxidation-reduction indicator. In 1955, the herbicidal properties of bipyridils were researched by Imperial Chemical Industries Ltd and the herbicidal nature of paraquat was established (Smith \& Heath, 1976). In the year 1962, paraquat was introduced to the market as a herbicide by the Plant Protection Division of Imperial Chemical Industries Ltd, which is now known as Syngenta (www2.syngenta.com/en/about_syngenta/companyhistory.html). It is the third bestselling pesticide in the world (www2.syngenta.com), and is especially popular in the developing countries (Wesseling et al., 2001).

Paraquat is extensively used all over the world because it is non-selective, fast acting, and small quantities are sufficient to efficiently kill weeds, thereby reducing competition for light, water and nutrients. Through use of paraquat, fields can be quickly prepared for farming, and rain does not affect the action of the herbicide. Paraquat is used on over 100 crops in more than 120 countries across the world (Wessling et al., 2001).

\subsubsection{Toxic effects and mechanism of action}

Paraquat is a non-selective herbicide that requires oxygen and light energy for its action. In green plants, the light energy captured by chlorophyll is transferred as electrons through photosystem I. In the presence of the reduced form of paraquat, the electrons from the Fe-S centres of photosystem I are diverted and react with paraquat (Conning et al., 1969) to generate superoxide anion $\mathrm{O}_{2}$ - This in turn generates hydroxyl radicals either directly or via the intermediary hydrogen peroxide. These highly reactive radicals cause deterioration of the cell membrane leading to cellular breakdown (Matile \& Moor, 1968). Browning of leaves is seen in a few hours in the presence of strong light and complete desiccation is observed in a few days. Fewer cases of resistance have been observed in comparison with resistance to herbicides with other modes of action.

Paraquat is extremely poisonous and use of the herbicide requires a licence in most countries. Use of paraquat has been banned in Finland, Austria, Sweden and Norway because of its high toxicity and frequency of poisonings (Wesseling et al., 2001). Paraquat manufactured by Syngenta, the leading producer of this herbicide, is blue in colour, has a sharp odour and contains an agent that causes vomiting, which helps prevent accidental consumption of the herbicide. Ingestion of a high dose of paraquat causes lung congestion, difficulty in breathing and an increase in heart rate. Cases of lung scarring have been reported when marijuana contaminated with paraquat was consumed. When the eyes come in contact with paraquat, it can cause corneal damage and scarring, while contact with skin leads to burns, damage to fingernails and dermatitis. Paraquat has been shown to be a mutagen to mouse, human and microorganisms; however there was no mutation observed in the sperm of male mice (Hazardous Substances Databank, 1995). There have been no adverse effects on reproduction or birth defects reported so far.

Paraquat toxicity depends on the amount, route and duration of exposure as well as the person's health at the time of exposure. Inhalation of paraquat can lead to acute respiratory distress syndrome whereas ingestion can cause direct damage to the lining of mouth or intestines. When ingested, it is distributed all over the body and toxic changes occur 
primarily in the lungs, liver and kidneys (Wagner, 1981). In humans, the lethal dose for ingestion is $35 \mathrm{mg} / \mathrm{Kg}$. Those suffering from respiratory infection are more susceptible to the toxic effects of paraquat. There is a high accumulation of paraquat in the lung tissue compared to other organs (Stevens \& Sumner, 1991).

Paraquat is exceedingly toxic to aquatic species such as rainbow trout, bluegill and channel catfish. At high concentration, it is shown to inhibit photosynthesis in certain types of algae. It is not known to accumulate in tissue; however, it can bioaccumulate in weeds. Paraquat can be found in residual form bound to aquatic weeds and bottom mud (Weed Science Society of America, 1994).

The chronic effects of paraquat in humans are Parkinson's Disease (PD) and severe lung damage (Wagner, 1981). In order to understand the environmental factors that make one susceptible to PD, a study of 120 patients was carried out in Taiwan. The study included 240 controls that were selected based on age and sex. The interview comprised questions related to the history of exposure to environmental factors such as source of drinking water, probability of environmental or occupational exposure, and use of herbicides or pesticides or exposure to paraquat. The results showed that exposure to paraquat caused an increase in susceptibility to PD (Liou, 1997).

A study from California showed that consumption of well water contaminated with paraquat increased susceptibility to PD by $20-50 \%$. Almost $91 \%$ of the study population was exposed to well water contaminated with paraquat (Gatto et al., 2009).

The predisposing factors for complex diseases such as PD are both genetic and nongenetic. Hence, it is necessary to study the joint effects of both these factors and in the case of genetic factors, the genes that are responsible for increasing the susceptibility to PD and the pathways these genes are involved in have to be identified. Out of the 1460 single nucleotide polymorphisms in the brain that have been identified in the axon guidance pathway, $183(12.5 \%)$ have been shown to increase susceptibility to PD (Lesnick, 2007).

\subsubsection{Development of animal models}

In 1983, Langston reported irreversible Parkinsonism (Langston et al., 1983) in a group of young drug addicts who used synthetic heroin contaminated with 1-methyl-4 phenyl1,2,3,6- tetrahydropyridine (MPTP). Since the contaminant caused symptoms of PD, monkey (Burns et al., 1983) and mouse (Heikkila et al., 1984) animal models of PD were developed by injecting sub lethal doses of MPTP. Animal models provide an opportunity to study the pathophysiology of PD and assist in development of successful treatment and prevention strategies. MPTP is metabolized into MPP+, which is structurally similar to paraquat. Since exposure to MPTP is minimal, but paraquat is a risk factor for PD, an animal model using paraquat is helpful for understanding the pathophysiology of PD.

Rat and mouse animal models have been developed to study the effect of exposure to paraquat, especially the neurotoxic effects. The toxic effect of paraquat on dopaminergic neurons is slow and this is reflected by the delayed and slow progression in the pathogenesis of PD. Both long and short term studies have been carried out on rats. Evans hooded rats showed loss of dopaminergic neurons in the substantia nigra region of the brain 
when intraperitoneal injections of paraquat were given weekly for three weeks. The neurons of the substantia nigra pars compacta region of the brain, which are autonomic pacemakers, produce high levels of reactive oxygen species and free radicals due to the accumulation of intracellular calcium. This results in DNA damage and high levels of neurodegeneration in this region. The paraquat-induced loss of neurons was shown by comparing tyrosine hydroxylase immunohistochemistry in the substantia nigra of paraquat injected rats with the substantia nigra of saline injected control rats. Loss of approximately $70 \%$ of the neurons was observed in the paraquat injected rats. Though not many differences can be seen visually, behavioural assessment using rotorod showed measurable changes between the two groups. Biochemical assays have shown that paraquat induces oxidative stress, indicating its neurotoxic effects. The reduced form of paraquat has been shown to cause an increase in reactive oxygen species (ROS) which is selective to brain cells (Castello et al., 2007). Subtle behavioural differences were also observed in the test and control rats (Somayajulu- Nitu et al., 2009). When a similar dose was given as intraperitoneal injections to Wistar rats for 4, 6, 8, 12, and 24 weeks and immunohistochemistry studies performed, a loss of approximately $37 \%$ in the dopaminergic neurons was observed (Ossowska et al., 2005).

Dopaminergic neuron loss in the substantia nigra and intra-neuronal deposition of asynuclein containing aggregates were also observed when C57BLJ/6 mice were injected intraperitoneally with paraquat $(10 \mathrm{mg} / \mathrm{Kg}$ body weight) weekly for three consecutive weeks (Manning-Bog et al., 2001). Similar studies have also been carried out with transgenic mice over-expressing a-synuclein and similar results have been obtained (Fernagut et al., 2007). The animal models help support the epidemiological link between paraquat used for agricultural purposes and PD. The C57BL/6 mouse strain has also been used for toxicology studies. When paraquat solution was applied to these mice through their nares, they showed lung pathology similar to those suffering from paraquat toxicity (Tomita et al., 2007).

\subsection{Rotenone}

\subsubsection{Background and history of use}

Rotenone is an insecticide and piscicide extracted from tropical leguminose. It was first isolated by Emmanual Geoffrey from the plant Robinia nicou while he was travelling in French Guiana. The details of the compound, which he called nicouline, were published posthumously in his thesis in 1895 after he died due to parasitic infection. However, rotenone has been used for many years by Africans and Asians to intoxicate fish and kill caterpillars.

Rotenone is now used in commercial gardens and is found in animal care products. It is marketed as an organic pesticide and piscicide and is available as dust, powder and spray formulations. The World Health Organisation has assigned rotenone as a moderately hazardous chemical; in Canada and USA, it is used only as a piscicide. It is also found in formulation with other pesticides such as carbaryl and lindane. It is manufactured by many companies and is available in 300 formulated products. It is effective against a large number of insect pests such as apple maggot, European corn borer, Pea aphid, Japanese beetle, Ladybird beetles, and predatory mites. 


\subsubsection{Toxic effects and mechanism of action}

Complex I, which is present in the inner mitochondrial membrane, is the first enzyme of the electron transport chain. This enzyme is encoded by the mitochondrial genome, unlike the other enzymes which are encoded by the nuclear genome (Hatefi, 1985). Rotenone inhibits complex I of the respiratory chain, resulting in a decrease in energy production.

The toxicity of rotenone depends on the nature of the plant extract and the species from which it is extracted. It is mildly toxic to hamsters or mice, whereas it is highly toxic to rats, especially the females. For humans the toxic dose is $300-500 \mathrm{mg} / \mathrm{Kg}$ for adults and 143 $\mathrm{mg} / \mathrm{Kg}$ for children. Human fatality due to rotenone has been reported very rarely because it causes immediate vomiting upon consumption. However, when the dust is inhaled it could lead to an increase in the rate of respiration followed by depression and convulsions (Uversky, 2004).

There have been no reports of endocrine disruption or teratogenic effects in humans. Studies on the carcinogenic effects of rotenone are still inconclusive. Studies on animal models of rotenone however show that it can produce symptoms of PD.

\subsubsection{Development of animal models}

Rotenone is involved in the pathogenesis of PD. Animal models of PD by exposure to various doses of rotenone for different durations have been developed to study the relationship between complex I and PD and also for preclinical testing of neuroprotective strategies. A number of genetic mouse models of PD are being developed; however, they fail to show the exact pathophysiology of PD. Hence, exposing the genetic mice to rotenone could help understand the link between genetic and environmental factors in the development of PD as well.

Sprague Dawley and Lewis rats were injected with varying doses of rotenone and it was shown that Lewis rats give more consistent results. A high dose of rotenone caused cardiovascular failure and non-specific brain lesions (Ferrante et al., 1997). However, a dose of 2-3 mg/Kg given for four weeks directly into the veins or subcutaneously resulted in PD-like symptoms. Rotenone was shown to act by inhibiting complex I, resulting in a decrease in the dopaminergic neurons in the substantia nigra region of the brain and also dopaminergic lesions (Hoglinger et al., 2005). The behavioural changes include unsteady movement and hunched posture. Severe rigidity was observed in some, whereas resting tremors were observed in others. Rotenone also caused loss of non- dopaminergic neurons in the basal ganglia and brainstem. The effect of rotenone was on neurons and not on oligodendrocytes, astrocytes or microglial cells. The drawback of the rotenone animal model is the variability in the effects of the same dose of rotenone, which clearly indicates the differences in the sensitivity of different strains of rat to the pesticide.

A group in Japan has shown that C57BL/6 mice, when orally fed with $30 \mathrm{mg} / \mathrm{Kg}$ of rotenone for 56 days, developed motor deficits, neurodegeneration of dopaminergic neurons and increases in the cytoplasmic accumulation of a- synuclein in the remaining dopaminergic neurons (Inden et al., 2011). Defects in complex I lead to a decrease in ATP synthesis which in turn induces mitochondrial depolarization and calcium deregulation. These factors cause an increase in the production of reactive oxygen species and hence 
oxidative stress (Sohal \& Weindruch, 1996). This, along with various genetic factors, results in the progression of neurodegenerative diseases. It has been shown that there is a $15-30 \%$ decrease in the activity of complex I in sporadic cases of PD (Betarbet et al., 2000). Rotenone, being lipophilic, crosses the cellular membranes and the blood brain barrier, becomes accumulated in the sub-cellular organelles such as mitochondria, inhibits complex I and impairs oxidative phosphorylation.

\subsection{Maneb}

\subsubsection{Background and history of use}

Maneb, a member of the ethylene bisdithiocarbamate (EBDC) group of fungicides, was first registered for use on both food and ornamental crops (EPA, 2005). These fungicides are used to protect crops in the field as well as to prevent them from deterioration during transportation and storage. The EBDC group includes mancozeb and metiram, and all three compounds degrade into ethylenethiourea (ETU). The EPA considers risk from ETU derived from maneb, mancozeb and metiram (EPA, 2005). In 1992 the EPA cancelled the use of EBDCs on a variety of fruits and vegetables. Despite these restrictions, approximately 2.5 million pounds of maneb are still used annually on fruit, vegetable and nut crops. There is no residential use and careful agricultural practices ensure that there is no risk of residential exposures to maneb. Lettuce, almonds, peppers and walnuts are the main crops treated with maneb, and the risks of exposure to this pesticide as of 2005 warranted its reduction or outright cancellation for use on certain crops (EPA, 2005).

\subsubsection{Toxic effects and mechanism of action}

Overall, maneb is considered only moderately toxic to humans (Occupational Health Services, 1991) and little is known about its mechanism of action. Maneb increased cellular glutathione in SH-SY5Y cells and produced no reactive oxygen species (Roede et al., 2011). Both maneb and its relative, mancozeb led to mitochondrial dysfunction and reduced ATP levels in rat mesencephalic cells (Domico et al., 2006). Maneb and mancozeb reduced active respiration linked to NADH (Domico et al., 2006) while manganese-EBDC (the major component of maneb) appeared to specifically inhibit mitochondrial complex III (Zhang et al., 2003). Interestingly, while maneb and mancozeb were both toxic to mesencephalic neurons, their metabolite ETU was not (Domico et al., 2006), indicating that in terms of neurotoxicity, it is the primary components of the EBDC pesticides that are most toxic to neurons, and not their product. Interestingly, the mitochondrial dysfunction caused by maneb led to a reduction in ATP, which has a subsequent impact on the functioning of the ubiquitin-proteasome system. This system is involved in the intracellular degradation of proteins, the failure of which leads to the collection of protein aggregates and is associated with PD (McNaught et al., 2001). Manganese-EBDC was neurotoxic and led to reduced proteasome activity in a dopaminergic neuronal cell line (Zhou et al., 2004), which led to cytoplasmic inclusions containing a-synuclein, a hallmark of PD. Dopaminergic cells exhibited increased oxidative stress and neurotoxicity in response to manganese-EBDC. Increasing antioxidant levels via acetylcystein increased cell viability and eliminated the manganese-EBDC-induced increase in oxidative stress (Zhou et al., 2004). 
Maneb has the interesting ability to potentiate the toxicity of other chemicals. Behaviorally, maneb intensified motor deficits experienced by mice treated with MPTP (Takahashi et al., 1989; Thiruchelvam et al., 2000b). The herbicide paraquat has a chemical structure very similar to that of $\mathrm{MPP}^{+}$, the active metabolite of MPTP. Thus, paraquat and maneb have been investigated for their combined ability to cause parkinsonian symptoms (Liou et al., 1997; Thiruchelvam et al., 2000a, 2000b). In a Taiwanese case study, PD risk was increased in those exposed to both paraquat and maneb (Liou et al., 1997). Exposure to this combination consistently led to significant changes in the nigrostriatal system (Thiruchelvam et al., 2000a, 2000b). In the presence of manganese-EBDC, striatal synaptosomes accumulated significantly more dopamine (Barlow et al., 2003). Toxicokinetic studies showed that manganese-EBDC given concurrently with paraquat led to more paraquat uptake by the brain than by other organs, indicating that the neurotoxicity of paraquat may be enhanced via maneb by directing more paraquat to be sequestered in the brain (Barlow et al., 2003).

It seems that exposure to both pesticides changes the mechanism of toxicity, at least as one study has shown. When tested independently, both paraquat and maneb triggered neuronal apoptosis via Bak, a pro-apoptotic member of the Bcl-2 gene family; however, when maneb and paraquat were tested together, Bak was inhibited and apoptosis was induced by the Bcl2 member Bax (Fei \& Ethell, 2008).

\subsubsection{Development of animal models}

Though there is evidence suggesting that exposure to the herbicide paraquat can contribute to PD, this model fails to take into account the overlap of areas exposed to other agrichemicals in addition to paraquat. This has led to the development of a mouse model of neurodegenerative disease using both maneb and paraquat to simulate exposure to both of these pesticides. In this model, male C57BL/6 mice (6 weeks old) were injected intraperitoneally with paraquat alone, maneb alone, or both paraquat and maneb (Thiruchelvam et al., 2000a, 2000b). The number of injections ranged from 4 (1 injection per week for 4 weeks; Thiruchelvam et al., 2000a) to 18 (2x per week for 9 weeks; Thiruchelvam et al., 2005). Essentially, the combined treatment with maneb and paraquat led to exacerbated effects on behavior, the dopaminergic system and the nigrostriatal system. Animals exhibited reduced locomotion, altered levels of dopamine and its metabolites, reduced dopamine transporter density and reduced number of dopaminergic neurons in the substantia nigra and striatum (Thiruchelvam et al., 2000a, 2000b). Unlike some other PD animal models, the maneb + paraquat model consistently induces a phenotype with impairments to both the motor system and nigrostriatal system.

The model has also been tested in a developmental context, where the mice were injected daily during post-natal days $5-19$, and re-challenged with pesticide injection at 6.5 months of age to determine how early exposure may effect subsequent exposure (Thiruchelvam et al., 2002). Overall, the authors found that exposing mice at a young age to paraquat and maneb made them more susceptible to pesticides as adults, as only those exposed postnatally experienced toxic effects to all three treatments as adults (e.g. paraquat, maneb, and paraquat + maneb). Additionally, mice exposed to the two pesticides early in development showed more deficits than mice exposed to single pesticides (Thiruchelvam et al., 2002). It appears as though the maneb + paraquat model has no benefit over paraquat alone in rats (Cicchetti et al., 2005; Xu et al., 2011). 
The combined paraquat and maneb system has been useful for investigating different neuroprotective or therapeutic agents, which may be helpful for people suffering from PD. Pre-treatment with lithium in the animal's food was able to eliminate a-synuclein protein aggregation and was neuroprotective against paraquat + maneb treatment of a-synuclein overexpressing transgenic mice (Kim et al., 2011). Similar neuroprotective effects were seen when mice exposed to maneb + paraquat were first treated with the naturally-occurring antioxidant silymarin or melatonin. Both silymarin and melatonin ameliorated the motor deficits induced by paraquat + maneb treatment such that these animals performed as well as control animals (Singhal et al., 2011). This striking effect may have been a consequence of silymarin's and melatonin's neuroprotective natures, as mice given one or the other prior to treatment with paraquat + maneb showed no significant loss of dopaminergic neurons in the substantia nigra (Singhal et al., 2011). Caffeine was also neuroprotective in the model, though the authors did not evaluate locomotor activity (Kachroo et al., 2010). Extract from the Polygonum multiflorum (PM) plant has also shown to be protective in this model. This herb has a long history in traditional Chinese medicine, and when given prior to and during exposure to maneb + paraquat, it was able to ameliorate the pesticide-induced motor deficits, reduction in striatal dopamine concentration and dopaminergic cell death (Li et al., 2005).

\subsection{Endosulfan}

\subsubsection{Background and history of use}

Endosulfan $\quad(6,7,8,9,10,10$-hexachloro-1,5,5a,6,9,9a-hexahydro-6,9-methano-2,4,3-benzadioxathiepin 3-oxide) is a broad-spectrum organochlorine contact insecticide registered for use on fruits, vegetables, cereal grains, cotton and ornamental trees and shrubs. Endosulfan was first patented in 1956 and its use is an estimated 1.38 million pounds of active ingredient on average from 1987 - 1997 (EPA, 2002).

Endosulfan has established toxic effects, is persistent in the environment and has the ability to bioaccumulate (Chopra et al., 2011). Endosulfan is being phased out of use in many countries including the United States (EPA, 2010) and Canada (Health Canada, 2011). At the $5^{\text {th }}$ meeting of the Conference of the Parties to the Stockholm Convention in 2011, endosulfan was banned globally. Strong opposition to this ban initially came from India, which uses and exports more endosulfan than any other country, with an estimated 113 kilotons used from 1958 - 2000 (Government of Canada, 2009). After a few concessions, India eventually agreed to the ban. The case of endosulfan use in India has a long and sordid history. Endosulfan has been applied to cashew crops via aerial spraying for over two decades. For years, residents of several villages in the Kasargod district of Kerala state had noticed increased illness and the death of animals, both wild and domestic, which seemed to coincide with the spraying (Adithya, 2009). Concerns of the villagers and doctors over the high rates of disease - including neurological disease, reproductive impairment, developmental problems and cancer - went largely unheard. Between 1998 and 2002, several groups, both national and international, conducted studies and concluded that endosulfan poisoning was responsible for the problems in Kasargod (Adithya, 2009; Quijano, 2002; Sivaraman et al., 2003). Doctors are now reporting a reduction in new cases since endosulfan was banned in Kerala in 2003 (Adithya, 2009). 


\subsubsection{Toxic effects and mechanism of action}

Endosulfan is in the same general class of pesticides as DDT, the organochlorine pesticides. The very mechanism of action of these pesticides - which is neurotoxicity - makes them toxic to all animals, not just the insect pests that they target. They cause disruptions to the neuronal membrane which in turn lead to altered sodium and potassium kinetics (Hays \& Laws, 1991). The result means that the sodium channel is not inactivated as normal, leading to a prolonged action potential (Hong et al., 1986; Soderlund \& Bloomquist, 1989). This is proposed to be the mechanism leading to seizures seen in endosulfan poisoning (e.g. Pradhan et al., 1997). Additionally, endosulfan and related compounds are antagonists of the chloride channel linked to the receptor for gamma-aminobutyric acid (GABA), the major inhibitory neurotransmitter in the brain, leading to over-excitation of neurons (Cole \& Casida, 1986; Klaassen, 1996).

There have been several recorded cases of acute accidental and non-accidental endosulfan poisoning in humans. In these cases, nearly all victims presented with seizure or convulsions, along with nausea and vomiting (Boereboom et al., 1998; Chugh et al., 1998; Karatas et al., 2006; Pradhan et al., 1997). In the case of 23 accidental poisonings (Karatas et al., 2006), all 23 people survived the insult. In one case of non-accidental poisoning, the patient died four days following exposure, the cause of death being cerebral edema (Boereboom et al., 1998). In a second case of non-accidental ingestion, the patient survived and appeared to be back to normal at a 3 month follow up (Pradhan et al., 1997). In a retrospective study of 52 cases of endosulfan intoxication, ingestion of the pesticide in excess of $35 \mathrm{~g}$ was the variable most likely to predict mortality (Moon \& Chun, 2009).

A variety of in vivo studies have demonstrated the effects of endosulfan on the central nervous system. Rats treated orally with endosulfan showed behavioral deficits such as an increased time to learn and retain a task in an operant learning paradigm (Lakshmana \& Raju, 1994), which may be related to alterations in neurotransmitter levels (Ansari et al., 1987, Lakshmana \& Raju, 1994). Increased serotonin levels following endosulfan were thought to lead to a motivational deficit in rats, since the animals showed problems with memory tasks but not motor tasks (Paul et al., 1994). Reduced GABA levels were detected in the offspring of female rats fed endosulfan during pregnancy (Cabaleiro et al., 2008), and neonatal exposure also led to an increase in shock-induced aggression (Zaidi et al., 1985). Male mice injected with endosulfan as juveniles and subsequently challenged as adults showed reduced concentrations of dopamine and its metabolite DOPAC in brain samples (Jia \& Misra, 2007).

There is a wealth of literature investigating the effects of endosulfan on the GABAergic system, and the ability of endosulfan to cause increased excitation in neurons is indicative of its neurotoxic nature. Fewer studies have directly investigated the toxic effects on neurons, either in culture or in vivo. The EPA's Federal Insecticide, Fungicide and Rodenticide Act guideline neurotoxicity studies failed to find overt signs of neuropathy associated with endosulfan treatment of rats (Silva \& Gammon, 2009). In rats, endosulfan led to engorged blood vessels in the meninges and cerebral hemorrhages (Singh et al., 2007). Endosulfan-treated rats were shown to have increased lipid peroxidation in cerebral tissue, a sign of damaging oxidative stress (Hincal et al., 1995). In vitro studies have shown that endosulfan inhibited proliferation and differentiation of neural stem cells while also inhibiting neurite formation (Kang et al., 2001). Additionally, PC 12 cells 
incubated with endosulfan were reduced in number, had unusual morphology and exhibited increased apoptosis (Yang et al., 2004). Although studies directly showing the ability of endosulfan to kill neurons are lacking, what is clearly known is that endosulfan interferes with the GABAergic system, causing over-excitation due to lack of GABA receptor-mediated inhibition. It is known that indirect excitotoxicity of this type leads to cell death in some pathologies, such as brain damage associated with chronic alcoholism (Dodd, 2002).

\subsubsection{Development of animal models}

In the case of endosulfan, animal models have been restricted to establishing the typical toxicological endpoints such as $\mathrm{LD}_{50}$ levels. It is clear that endosulfan has a toxic effect on the brain, but there is no clearly established animal model developed in order to evaluate its role specifically in neurodegenerative disease. In fact, there are relatively few in vitro studies showing that endosulfan is capable of killing neurons. Given the global ban on endosulfan, the establishment of an animal model for continued neurotoxicity testing seems somewhat unnecessary, except for studying the long-term effects of endosulfan exposure, as exposed populations still exist. Given the number and variety of pesticides that human populations are exposed to regularly, it seems unlikely that a banned substance will continue to be researched in the way that endosulfan has in the past.

\subsection{Atrazine}

\subsubsection{Background and history of use}

Atrazine (6-chloro- $N^{2}$-eyhyl- $N^{4}$-isopropyl-1,3,5-triazine-2,4-diamine) is one of the most heavily used herbicides in the United States, with an estimated use of 76.5 million pounds per year (EPA, 2003). Atrazine was first registered for use as an herbicide by JR Geigy SA (currently known as Syngenta) in 1958, and is widely employed in the control of broadleaf plants (EPA, 2003; Gammon et al., 2005). Measures were taken in the 1990s to reduce the amount of atrazine contamination in surface and groundwater, including the establishment of a Maximum Contaminant Level of 3 parts per billion for atrazine (EPA, 2003). Despite established usage limits, data show that the overall use of atrazine has changed very little since the late 1980s (Kiely et al., 2004). Approximately 80 million pounds of atrazine are applied annually (Kiely et al., 2004), with particularly heavy usage on corn, sorghum and sugarcane. In fact, atrazine is the main pesticide used on these three crops, and treatment with atrazine amounts to $75 \%$ of all American corn, $58.5 \%$ of all sorghum and $76 \%$ of all sugarcane (EPA, 2003). In addition to its pervasive use in agriculture, atrazine is also used in residential settings and on golf courses, adding to the potential for human exposure, though data on these routes of exposure are lacking. Oral exposure through food consumption of atrazine is very low (Ribaudo \& Bouzaher, 1994), but the chemical properties of atrazine mean that it enters surface and groundwater through leaching and runoff (Ribaudo \& Bouzaher, 1994). Exposure through drinking water is the most likely route of exposure for the majority of the American population, except for occupational exposure experienced by atrazine applicators and farmers and their families, who are at an increased risk of exposure (Curwin et al., 2007). A complete European ban on atrazine came into effect between 2005 2007 (Ackerman, 2007). Given the estimated economic impacts of banning atrazine in the United States, it is unlikely that total or even partial bans on its use are forthcoming 
(Ribaudo \& Bouzaher, 1994). Whether or not these estimated impacts are realistic is another question (Ackerman, 2007), and the use of atrazine in the United States remains a contentious issue.

\subsubsection{Toxic effects and mechanism of action}

Atrazine functions as an herbicide by inhibiting photosynthesis in the target plant. Specifically, atrazine prevents electron transfer at complex II in the chloroplast (Gysin \& Knuesli, 1960). Thus, the mechanism of toxicity is similar to the mechanism whereby dopaminergic neurons are killed in the paraquat model of PD (Franco et al., 2010).

The possible neurotoxic effects of atrazine are much less researched than the endocrine effects, which have received much attention. Despite the lower number of studies, there is evidence that atrazine is neurotoxic. Atrazine administered orally is capable of crossing the blood-brain barrier and could be measured in brain tissue, along with didealkyl atrazine, its major metabolite (Ross et al., 2009). A small body of literature has examined the neurotoxic effects of atrazine in both in vitro and in vivo studies. Many of these studies show damage which is similar to that seen in neurodegenerative diseases such as PD. In vivo, both chronic and acute exposures to atrazine affect brain monoamine systems with associated changes to behavior. Behavioral effects vary, however, such that dietary atrazine treatment led to hyperactivity after 6 months of treatment (Rodríguez et al., 2005), or hypoactivity after 8 months of treatment (Bardullas et al., 2011). Different strains used (Long-Evans versus Sprague-Dawley) might account for these results, or the fact that testing continued throughout the year, which might have affected activity levels overall (Bardullas et al., 2011). Atrazine treatment also impaired performance in learning tasks (Bardullas et al., 2011).

The in vivo chronic treatment of rats with atrazine also leads to alterations in brain neurotransmitter levels. After 6 or 12 months of atrazine, dopamine levels were reduced in the striatum (Bardullas et al., 2011; Rodriguez et al., 2005), and norepinephrine levels were reduced in the prefrontal cortex (Rodriguez et al., 2005). In fact, dopamine and its metabolites were reduced in the murine striatum after as few as 14 days of atrazine exposure (Coban \& Filipov, 2007). After 6 months, serotonin was reduced in the hypothalamus (Rodriguez et al., 2005), and in the striatum after 14 days (Coban \& Filipov, 2007), while reduced serotonin was not seen after 12 months in a separate experiment (Bardullas et al., 2011). Atrazine treatment reduced numbers of tyrosine hydroxylase immunoreactive neurons in the substantia nigra pars compacta and the ventral tegmental area (Coban \& Filipov, 2007; Rodriguez et al., 2005), indicating that it is neurotoxic to dopaminergic neurons. Atrazine also caused general neurodegeneration in the hippocampus of the female mouse (Giusi et al., 2006). In vivo microdialysis experiments further showed that dopamine release in the striatum is reduced as a consequence of an acute exposure to atrazine (Rodríguez et al., 2005).

In vitro studies show that exposure to atrazine disrupts the dopaminergic system. Studies using striatal slices showed that atrazine treatment lowered the level of dopamine released in the striatum, but it did not affect the level of the rate-limiting enzyme tyrosine hydroxylase. There is an indication that the reduction in dopamine could be associated with a decrease in dopamine-producing neurons in the substantia nigra (Filipov et al., 2007). 
Additionally, the uptake and sequestration of dopamine into vesicles appeared impaired and perhaps as a consequence of this, the ratio of dopamine metabolites/dopamine increased (Filipov et al., 2007; Hossain \& Filipov, 2008). PC12 cells are neuronal cells derived from a tumour of the rat adrenal medulla that produce catecholamines including dopamine. Intracellular dopamine concentration was reduced in undifferentiated PC12 cells treated with atrazine, and the relationship was dose-dependent, while tyrosine hydroxylase levels, though slightly reduced, were not significantly effected (Das et al., 2000; Das et al., 2003). Intracellular norepinephrine was decreased and the cells exhibited reduced norepinephrine release and reduced dopamine $\beta$-hydroxylase, the enzyme which converts dopamine to norepinephrine (Das et al., 2000; Das et al., 2003). Moreover, atrazine metabolites produced unique and varying effects on dopamine and norepinephrine release in PC12 cells, with certain metabolites increasing levels of dopamine and/or norepinephrine, and other decreasing catecholamine levels (Das et al., 2001).

\subsubsection{Development of animal models}

Unlike other herbicides, a standard model for testing the neurodegenerative effects of atrazine has not been established. The chemical has been tested on rats and mice in vivo, but the protocols vary in terms of route of administration, dose, time, animal strain and endpoint. Before atrazine can be firmly established as a confirmed neurotoxicant, these parameters need to be standardized. A lack of standardization across studies may help to account for differences seen in results, and though these studies point to atrazine as being a toxic agent, the link remains tenuous. Behavioral endpoints need to be established to help further demonstrate the detrimental effects of atrazine. It has been demonstrated in cell culture and brain slice preparations that atrazine negatively impacts the catecholaminergic system, but the long-term ramifications of this toxicity are not clear, and need to be known in order to say with more confidence that atrazine is linked to neurodegenerative disease.

\subsection{Aldrin/dieldrin}

\subsubsection{Background and history of use}

Aldrin is an organochlorine insecticide which breaks down into dieldrin. It is a PBT chemical, meaning that it is persistent, bioaccumulative and toxic. Aldrin was widely used in the United States to control insect infestations on corn, cotton and citrus until it was completely banned for agricultural use in 1985 amid health concerns (EPA Persistent Bioaccumulative and Toxic (PBT) Chemical Program, 2011). However, given its persistent nature, aldrin is still found in the environment where humans and animals may still be at risk of exposure. Since the majority of the literature concerns specifically dieldrin, it is dieldrin that will primarily be covered here.

\subsubsection{Toxic effects and mechanism of action}

As an organochlorine insecticide, dieldrin is similar in action to endosulfan. It kills insects via the same mechanism as endosulfan, by inhibiting GABA receptors and causing neuronal over-excitation (e.g. Ikeda et al., 1998). Dieldrin is neurotoxic, particularly to dopaminergic cells (reviewed by Kanthasamy et al., 2005). Dieldrin produced time- and dose-dependent 
increases in neurotoxicity in both GABAergic and dopaminergic cells in mesencephalic cell culture, but the effect was more pronounced in the dopaminergic neurons (Sanchez-Ramos et al., 1998). Moreover, dieldrin was toxic to dopaminergic PC12 cells at lower doses than it was to both pancreatic endocrine cells and human cortical neurons (Kitazawa et al., 2001). Dieldrin may be toxic to dopaminergic neurons by producing reactive oxygen species (ROS). Treatment of dopaminergic SN4741 cells with dieldrin lead to a slow increase in ROS production, particularly $\mathrm{H}_{2} \mathrm{O}_{2}$, which eventually led to apoptosis (Chun et al., 2001). ROS combines with nitric oxide, producing reactive nitrogen species which affect the respiratory chain of the mitochondria resulting in a decrease in ATP synthesis and increase in lipid peroxidation (Ebadi \& Sharma, 2003). These changes in the membrane properties affect cellular homeostasis leading to dysfunction of the mitochondria and neurotoxicity.

In addition to killing dopaminergic neurons, dieldrin may also cause dopamine dysfunction. While Thiffault and colleagues (2001) found that treating mice with a single injection of dieldrin was insufficient to cause any reduction in dopamine or its metabolites in the striatum, long term exposures have the potential to severely alter normal brain chemistry. Mice exposed for 30 days showed decreases in dopamine metabolite levels, as well as decreases is dopamine transporter expression in the striatum (Hatcher et al., 2007). Developmental exposure to dieldrin appears to be detrimental as well, as female mice exposed to low diedrin levels had offspring that were predisposed to increased toxicity from other agents (Richardson et al., 2006). Additionally, at 12 weeks of age, mice exposed in utero showed dose-dependent increases in dopamine transporter and vesicular monoamine transporter 2 mRNA levels, indicative of dopamine dysfunction, and opposite to what was seen with post-natal exposures.

Dieldrin produces contrary effects on dopamine efflux in PC12 cells. Extracellular dopamine was increased while intracellular levels were decreased when dopamine content was measured via HPLC (Kitazawa et al., 2001). When measured in PC12 cells loaded with radionuclide-labeled dopamine, dopamine efflux was found to be inhibited in the presence of dieldrin (Alyea \& Watson, 2009). Time course and other methodological differences could account for these contradictory results.

\subsubsection{Development of animal models}

As is the case with several of the pesticides mentioned above, there has been little progress in terms of the formal development of an animal model for investigating the neurotoxic effects of dieldrin. Although dieldrin has often been administered directly to mice (Hatcher et al., 2007; Richardson et al., 2006; Thiffault et al., 2001) these studies have used varying treatment parameters, meaning that often conflicting results must be evaluated carefully. The ban on dieldrin also means that there is less interest in fully establishing its status as a factor in neurodegeneration, and it is unlikely to see further development as a model of PD. However, dieldrin still persists in the environment, making low-dose chronic exposure studies all the more important. Organochlorines appear to be particularly high risk factors for the development of neurodegenerative disease (Seidler et al., 1996) and the toxicity of dieldrin, endosulfan and DDT are not in dispute. The development of a standardized animal model for testing dieldrin will not only help to further identify its particular neurotoxicity, but may also help contribute to our overall understanding of how the organochlorines may contribute to PD development. 


\section{Evidence for a correlation of herbicide exposure and neurodegenerative disease}

Animal models of pesticide contribution to neurodegenerative disease are largely focussed on the development of Parkinson's disease. These have been discussed in the above section. For the purpose of reviewing additional evidence for correlation of pesticide exposure and the development of neurodegenerative disease, this section will discuss the human epidemiological evidence. This section will further be divided into reviews of the neurodegenerative diseases most often associated with pesticide exposure: Parkinson's disease, Alzheimer's disease and Amyotrophic lateral sclerosis.

\subsection{Parkinson's disease (PD)}

Interest in the association of PD and pesticide exposure by sparked with the observation nearly 30 years ago that exposure to the chemical MPTP caused PD symptoms (Langston et al., 1983). MPP+, the toxic metabolite of MPTP which is structurally similar to paraquat, is selectively uptaken by dopaminergic neurons. Recently, the epidemiology of PD has been extensively reviewed, including thorough reviews of the association between PD and pesticides (Brown et al., 2006; Wirdefeldt et al., 2011). The epidemiological data for pesticide exposure and PD are extensive, and the following review is not meant to be exhaustive.

In examining the case-controlled literature, Wirdefeldt and colleagues found that there were 38 published case-control studies looking at pesticide exposure and incidence of PD. Of these, exactly half found a positive association, and half found no association (Wirdefeldt et al., 2011). When 31 of the studies were presented in a forest plot, it was clear that although half of the 38 case-controlled studies found no significant association, most of the studies still report increased risk for the case group (Brown et al., 2006). When these studies were further broken down into those which attempted to examine the effects of different types of pesticides (herbicides, fungicides, insecticides and organochlorines), herbicide exposure was positively associated with PD, as was insecticide exposure (Brown et al., 2006). In one study, after controlling for additional pesticide exposure, herbicide exposure was still a significant independent risk factor for PD (Semchuk et al., 1992). Paraquat exposure specifically presented a significant risk (Hertzman et al., 1990; Liou et al., 1997), and risk was increased, though non-significantly, in other studies (Firestone et al., 2005; Hertzman et al., 1994). Overall, this indicated that there is a link between Paraquat exposure and the incidence of PD. In a meta-analysis of 19 studies, the authors calculated a combined odds ratio for PD risk of 1.94, indicating a positive association (Priyadarshi et al., 2000).

There appear to be several factors influencing the possibly that an individual will develop $\mathrm{PD}$ as a consequence of exposure to agrichemicals. Studies indicate that there may be a critical period of exposure, as greater risk was associated with exposure at specific age periods (Semchuk et al., 1992). Perhaps exposure duration is a more important factor, as several studies indicate that risk increases with an increasing duration of exposure, particularly in excess of 10 or 20 years (Gorell et al., 1998; Liou et al., 1997; Seidler et al., 1996). As with some other toxins, the danger may be in the dose, as there was a greater association seen with high doses compared to low doses (Nelson et al., 2000, as cited in Brown et al., 2006) although trying to determine dose in case-controlled studies is often 
tricky and imprecise, and in other cases, the relationship between dose and risk may even be reversed (Kuopio et al., 1999). Most likely, it is a combination of long duration and high dose that has a greater effect on risk (Nelson et al., 2000, as cited in Brown et al., 2006; Seidler et al., 1996).

PD risk is also associated with different - but related - environmental factors such as rural living, farming and drinking well water. Studies have shown higher occurrence of PD in rural versus urban areas in Canada (Barbeau et al., 1987), the United States (Lee et al., 2002), and Denmark (Tuchsen et al., 2000). Drinking well water is a risk factor for PD (Tsai et al., 2002); however, this tends to be dependent on rural living, so the two factors are interrelated (Koller et al., 1990). If farming is a legitimate risk factor for PD, it is difficult to detect in casecontrol studies. Wirdefeldt and colleagues (2011) report that of 34 case-control studies that considered farming and PD prevalence, there was significantly increased risk in only 7 studies. A meta-analysis published by Priyadarshi and colleagues (2001) found an association with farming in the United States (including exposure to farm animals or living on a farm). The meta-analysis is of interest because the authors calculated odds ratios based on all the existing published data, rather than just grouping the studies together based on whether or not the original authors found a significant association.

Several confounding factors need to be addressed in these studies. For example, smoking is negatively correlated with PD incidence, but very few case-control studies have corrected for smoking. Defining pesticide exposure is challenging, and considering this, it is not surprising that few studies manage to find a significant association. Exposure assessment largely relies on the ability of the patient to recall their exposure based on general questions, and often these questions aren't given in the published study. Exposure is often defined in a dichotomous way. Where exposures are residential or non-occupational, patient recall may be unreliable. Clearly there needs to be a more reliable and objective way of establishing pesticide exposure. Specific biomarkers could be used, or tissue samples could be analyzed for pesticide concentrations. For example, higher levels of dieldrin (Corrigan et al., 1998) and lindane (Corrigan et al., 2000) were detected in brain samples taken from PD patients post-mortem. Increasing plasma dieldrin levels were also associated with PD in never smokers (Weisskopf et al., 2010). For a persistent organic pollutant such as dieldrin, this is simple enough, but it may be troublesome for pesticides which break down more rapidly, or do not accumulate.

All of us are exposed to pesticides and environmental toxins on a regular basis and the incidence of PD does not seem to reflect this fact. Humans have evolved biological mechanisms for the detoxification and metabolism of xenobiotics, and it is feasible that perturbations in these mechanisms could help determine whether or not an individual develops a neurodegenerative disease in response to pesticides. Individuals with mutations in the CYP2D6 gene - which is responsible for metabolizing environmental toxicants - may lack sufficient means to remove toxins before they contribute to neurodegeneration. These individuals have been termed "poor metabolizers" and show undetectable CYP2D6 activity (reviewed by Elbaz et al., 2007). There appears to be a strong association between CYP2D6 dysfunction and PD occurrence.

Overall, the evidence suggests an association between pesticide exposure and PD risk. Brown and colleagues (2006) demonstrated that this may be particularly true for herbicide 
exposure. Future epidemiological studies need to include certain methodological considerations, chiefly exposure assessment in non-occupational situations. Additionally, studies need to accurately assess additional factors such as smoking and control for these factors in statistical analyses.

\subsection{Alzheimer's disease (AD)}

There is little evidence for the role of pesticide exposure in the development of AD, the most common type of dementia. As with PD, rural living is associated with higher incidence rates of AD in countries including Italy (Rocca et al., 1990) and Finland (Sulkava et al., 1988). A recent study conducted in the Andalusia region of Spain found that there was a greater risk of developing AD in districts with high pesticide use (Parrón et al., 2011).

There are two case studies in the literature which describe individuals aged 55 (Cannas et al., 1992) and 59 (Lake et al., 2004) diagnosed with AD who experienced long-term occupational pesticide exposure. These case studies offer little evidence that chronic pesticide exposure can lead to $\mathrm{AD}$, but occupational exposure is a legitimate risk factor. $\mathrm{A}$ study investigating neurodegenerative disease incidence in different occupations found increased AD (and PD) in non-horticultural farmers below the age of 65 (Park et al., 2005). In a cohort study of the elderly in France, occupational exposure to pesticides decreased cognitive performance and increased risk of developing both AD and PD in men (Baldi et al., 2003). A study of the residents of an agricultural community in Utah found increased risk of $\mathrm{AD}$ and dementia among those exposed to pesticides, with organophosphate pesticides being identified as particularly dangerous (Hayden et al., 2010), while a casecontrol study conducted in Quebec, Canada found no significant risk of AD with exposure (Gauthier et al., 2001). However, an analysis of the Canadian Study of Health and Aging looking at 258 cases of clinically diagnosed AD found a positive association with pesticides (Canadian Study on Heath and Aging Working Group, 1994). Compared to PD, there is more consensus that pesticide exposure increases risk of AD. Although there have been very few studies, most have found a significant association.

\subsection{Amyotrophic lateral sclerosis (ALS)}

ALS is a motor neuron disease caused by the degeneration of neurons in the brain and spinal cord. As with $\mathrm{AD}$, there is little scientific literature on the correlation between pesticides and development of ALS, although from what little data are available, there does appear to be a relationship. Of 6 identified epidemiological studies that included pesticide risk of ALS, 5 of these found a significant association. Most recently, in a case-control study of ALS in northern Italy, Bonvicini and colleagues (2010) found that compared to age- and sex-matched controls, more ALS cases had experienced occupational pesticide exposure in excess of 6 months. There was an increased risk of ALS among employees of the Dow Chemical Company who were exposed to the herbicide 2,4-dichlorophenoxyacetic acid versus other Dow employees (Burns et al., 2001). Similar studies have found positive associations for populations exposed to pesticides (McGuire et al., 1997; Qureshi et al., 2006), and the relationship was found to be dependent on dose (Morahan \& Pamphlett, 2006). Overall, the relationship tends to be stronger for males than females (McGuire et al., 1997; Morahan \& Pamphlett, 2006). In one study using participants in the American Cancer 
Society's Cancer Prevention Study II, no association between pesticide exposure and ALS was detected (Weisskopf et al., 2009).

Although epidemiological studies are lacking, there are other hypotheses regarding how pesticide exposures may contribute to ALS. Evidence suggests that certain individuals are genetically susceptible to ALS due to mutations in specific genes which are involved in the handling and detoxification of xenobiotics. The paraoxonase enzymes are responsible for detoxifying organophosphates and are coded for by the genes PON1-3. These genes have been implicated in the development of ALS through pesticide exposure. When investigating PON polymorphisms in a control population versus a population exposed to organophosphates, Sirivarasai and colleagues (2007) found that the exposed group exhibited three polymorphisms in PON1 that were not observed in the control group. The exposed group also had reduced enzyme levels (Sirivarasai et al., 2007). A number of studies have found polymorphisms in the PON locus to be positively associated with ALS (Cronin et al., 2007; Landers et al., 2008; Saeed et al., 2006; Slowik et al., 2006; Valdmanis et al., 2008). However, the data are far from conclusive, and a recent meta-analysis failed to find a significant association between ALS and PON (Wills et al., 2009).

In conclusion, given the evidence presented above, occupational exposure to pesticides appears to present a significant risk for developing various neurodegenerative diseases. Certain allelic mutations may pre-dispose individual to increased toxicity from pesticides if they lack sufficient detoxification mechanisms. Case-control studies have proven useful for establishing links between exposure and disease development, but certain methodological considerations must be addressed. Studies must control for certain confounding factors such a smoking, and pesticide exposure assessment should be standardized and refined.

\section{Recent advances in the development of neuroprotective agents}

Neurons are post-mitotic, that is they do not undergo cell division. Hence, populations of neurons that have been killed cannot be easily replaced by surviving cells. These cells are also more susceptable to oxidative stress in comparison to other cell types. Morevoer, there is an increase in oxidative stress and hence oxidative damage with age. In PD, the patient remains asymptomatic until $50 \%$ of the neurons in the substantia nigra are lost. No drug designed so far can prevent neurodegeneration and halt the progression of the disease. The primary treatment available for PD is administration of dopamine agonists which inhibit dopamine degradation and provide temporary symptomatic relief (Obeso et al., 2000). The use of antioxidants such as Vitamin E has failed for PD, though it has shown more positive results for diseases such as AD and ALS (Sano et al., 1997; The Parkinson's Study Group, 1993).

Levodopa - L-3, 4-dehydroxyphenylalanine is a standard, highly effective drug used for the treatment of PD and other therapies that are being studied are usually compared to it (Fahn, 1999). Upon crossing the blood brain barrier, levodopa is converted to dopamine by the enzyme L- aminodecarboxylase. When levodopa is converted to dopamine, dopamine receptors are activated which in turn lessens the symptoms of PD. Levodopa is more effective in higher doses in comparison with lower doses; however, the high dose might result in adverse effects such as dyskinesia (Fahn et al., 2004). 
Levodopa does not cure PD and the dose might have to be standardised for each patient.

The substantia nigra region of the brain is prone to high oxidative stress even under normal conditions because of the high levels of reactive metabolites produced by dopamine. Using neuroprotective agents that reduce oxidative stress and protect the mitochondria, thereby decreasing neurodegeneration, would be the ideal therapy for PD. Coenzyme Q10 (CoQ10), a naturally occurring compound that participates in the electron transport chain, is an effective antioxidant. Both fat and water soluble CoQ10 have been used for animal and preclinical studies. The clinical trial for fat soluble CoQ10 formulation in the treatment of PD has been halted as it was not effective. The water soluble formulation (www.zymes.com/) of CoQ10 (consisting of CoQ10, polyethylene glycol, and a- tocopherol) however, has been shown to be an effective prophylactic agent that prevents progression to PD. A dose of 50 $\mu \mathrm{g} / \mathrm{ml}$ has shown to be effective in preventing the degeneration of dopaminergic neurons in Long Evans Hooded rats injected with paraquat (Somayajulu-Nitu et al., 2009). These rats did not show PD - like symptoms and there was no motor impairment or decrease in the number of dopaminergic neurons. Water soluble CoQ10 may also be useful as a therapeutic treatment for PD (Facecchia et al., unpublished data)

Pre-treatment of C56BL/6 mice with caffeine before injecting them with a combination of maneb and paraquat helps reduce the loss of dopaminergic neurons. A chronic dose of 20 $\mathrm{mg} / \mathrm{Kg}$ increased the expression of tyrosine hydroxylase in the substantia nigra region (Kachroo et al., 2010).

Other neuroprotective agents that have been studied and have shown positive results are silymarin and melatonin (Singhal et al., 2010). Lithium feeding for a period of three months prevented accumulation of a- synuclein in nine - month old a- synuclein transgenic mice that were injected with paraquat and maneb. It also protected a-synuclein enhanced green fluorescent protein overexpressing dopaminergic N27 cells that were treated with hydrogen peroxide (Kim et al., 2011).

Polygonum multiflorium is a Chinese herb and its extract contains an ethanol soluble fraction and an ethanol insoluble fraction. The ethanol soluble fraction has been shown to prevent a decrease in the number of dopaminergic neurons in the substantia nigra region of C57BL/6 mice injected with paraquat and maneb twice a week for six weeks (Li et al., 2005).

Autophagy is an inducible process that is activated by factors such as stress, pathogenic invasion, or nutrient or growth factor deprivation. Mutation of genes such as a- synuclein and tau could result in the expression of misfolded and aggregated proteins that can be removed by autophagy enhancement thereby preventing neurodegeneration (Pan et al., 2009). Feeding mice with $1 \%$ trehalose for 2.5 months has been shown to decrease PD - like symptoms in transgenic mice with mutation in the tau gene (Rodriguez- Navarro et al., 2010).

\section{Conclusions and recommendations}

In conclusion, we have provided evidence that environmental exposures to pesticides can contribute to the development of neurodegenerative diseases. Typical toxicological testing does not normally account for the neurotoxic effects of pesticides, rather, these tests focus on establishing LC50 values and evaluating toxicity to organs such as kidney, liver and lungs. 
Neurotoxicity testing seldom evaluates the effects of long-term, low-dose exposure to pesticides, which is a much more likely human exposure scenario. We suggest that longterm low-dose in vivo and in vitro testing of pesticides for neurotoxicity should become standard procedure before introducing new products into the environment. Neurons are particularly susceptible to long-term exposure to toxic chemicals given their post-mitotic and non-regenerating nature. Neurotoxicology studies should examine biochemical, behavioral and histological effects of pesticide exposure in order to establish a more complete picture of the potential toxicity of chemicals. Moreover, behavioral testing should examine not only motor effects, but also deficits in learning, memory or cognition (Walsh \& Chrobak, 1987), which may not be as overt but are still highly detrimental. Although mammalian models have long been the standard for toxicity testing, non-mammalian systems are becoming more common, and present new alternatives for long-term neurotoxicity testing (Peterson et al., 2008). Histological examination of the brain for signs of toxicity is obviously an important consideration. Assessing neurodegeneration in the dopaminergic system, particularly the substantia nigra, may be considered as a parameter for neurotoxicity testing, given the apparent susceptibility of the dopaminergic system to a variety of compounds, some pesticides included (Storch et al., 2004). Hopefully, future toxicity studies will consider the potential of a pesticide to induce cell death specifically in the brain, and probable neurotoxicants will be kept out of the environment.

\section{Acknowledgements}

The authors wish to thank Miss. Manika Gupta for critical reading of this manuscript and for providing valuable comments. We gratefully acknowledge funding from the Natural Science and Engineering Research Council of Canada, Canadian Institute for Health Research, and the Michael J. Fox Foundation NY.

\section{References}

Ackerman, F. (2007). The economics of atrazine. International Journal of Occupational and Environmental Health. Vol.13, No.4, (October-December 2007), pp. 441-449.

Adithya, P. (2009). India's endosulfan disaster. A review of the health impacts and status of remediation. Thanal. July 2011, Available from: http:/ / p7953.typo3server.info/panfiles/download/endosulfan-aditya.pdf

Alyea, RA., \& Watson, CS. (2009). Differential regulation of dopamine transporter function and location by low concentrations of environmental estrogens and $17 \beta$-estradiol. Environmental Health Perspectives. Vol.117, No.5, (May 2009), pp. 778-783.

Ansari, RA., Husain, K., \& Gupta, PK. (1987). Endosulfan toxicity influence on biogenic amines of rat brain. Journal of Environmental Biology. Vol.8, No.3, pp. 229-236.

Baldi, I., Lebailly, P., Mohammed-Brahim, B., Letenneur, L., Dartigues, JF., \& Brochard, P. (2003). Neurodegenerative diseases and exposure to pesticides in the elderly. American Journal of Epidemiology. Vol.157, No.5, (March 2003), pp. 409-141.

Barbeau, A., Roy, M., Bernier, G., Campanella, G., \& Paris, S. (1987). Ecogenetics of Parkinson's disease: prevalence and environmental aspects in rural areas. Canadian Journal of Neurological Sciences. Vol.14, No.1, (February 1987), pp. 36-41.

Bardullas, U., Giordano, M., \& Rodríguez, VM. (2011). Chronic atrazine exposure causes disruption of the spontaneous locomotor activity and alters the striatal 
dopaminergic system of the male Sprague-Dawley rat. Neurotoxicology and Teratology. Vol.33, No.2, (March-April 2011), pp. 263-272.

Barlow, BK., Thiruchelvam, MJ., Bennice, L., Cory-Slechta, DA., Ballatori, N., \& Richfield, EK. (2003). Increased synaptosomal dopamine content and brain concentration of paraquat produced by selective dithiocarbamates. Journal of Neurochemistry. Vol.85, No.4, (May 2003), pp. 1075-1086.

Betarbet, R., Sherer, T B., MacKenzie, G., Garcia-Osuna, M., Panov, A V., \& Greenamyre, JT. (2000) Chronic systemic pesticide exposure reproduces features of Parkinson's disease. Nature Neuroscience.Vol.3, No.12, (December, 2000) pp.1301-1306.

Boereboom, FT. van Dijk, A., van Zoonen, P., \& Meulenbelt, J. (1998). Nonaccidental endosulfan intoxication: a case report with toxicokinetic calculations and tissue concentrations. Journal of Toxicology. Clinical Toxicology. Vol.36, No4, pp. 345-352.

Bonvicini, F., Marcello, N., Mandrioli, J., Pietrini, V., \& Vincenti, M. (2010). Exposure to pesticides and risk of amyotrophic lateral sclerosis: a population-based case-control study. Annali dell'Istituto Superiore di Sanità. Vol.46, No.3, pp. 284:287.

Brown, TP., Rumsby, PC., Capleton, AC., Rushton, L., \& Levy, LS. (2006). Pesticides and Parkinson's disease--is there a link? Environmental Health Perspectives. Vol.114, No.2, (February 2006), pp. 156-64.

Burns, RS., Chineh, RS., Markey, SP., Ebert, MH., Jacobowitz, DM., Kopin, IJ. (1983). A primate model of parkinsonism: selective destruction of dopaminergic neurons in the pars compacta of the substantia nigra by N-methyl-4-phenyl-1,2,3,6tetrahydropyridine. PNAS. Vol. 80, No. 14, (July, 1983) pp.4546-4550.

Burns, CJ., Beard, KK., \& Cartmill, JB. (2001). Mortality in chemical workers potentially exposed to 2,4-dichlorophenoxyacetic acid (2,4-D) 1945-94: an update. Occupational and Environmental Medicine. Vol.58, No.1, (January 2001), pp. 24-30.

Cabaleiro, T., Caride, A., Romero, A., \& Lafuente, A. (2008). Effects of in utero and lactational exposure to endosulfan in prefrontal cortex of male rats. Toxicology Letters. Vol.176, No.1, (January, 2008), pp. 58-67.

Castello, PR., Drechsel, DA., \& Patel, M. (2007). Mitochondria are a major source of paraquat-induced reactive oxygen species production in the brain. The Journal of Biological Chemistry. Vol.282, (March, 2007), pp. 14186-14193.

Canadian Study of Health and Aging Working Group. (1994). The Canadian Study of Health and Aging: risk factors for Alzheimer's disease in Canada. Neurology. Vol.44, No.11, (November 1994), pp. 2073-2080.

Cannas, A., Costa, B., Tacconi, P., Pinna, L., \& Fiaschi, A. (1992). Dementia of Alzheimer type (DAT) in a man chronically exposed to pesticides. Acta Neurologica. Vol.14, No3, (June 1992), pp. 220-223.

Chopra, AK., Sharma, MK., \& Chamoli, S. (2011). Bioaccumulation of organochlorine pesticides in aquatic system--an overview. Environmental Monitoring and Assessment. Vol.173, No.1-4, (February 2011), pp. 905-916.

Chugh, SN., Dhawan, R., Agrawal, N., \& Mahajan, SK. (1998). Endosulfan poisoning in Northern India: a report of 18 cases. International Journal of Clinical Pharmacology and Therapeutics. Vol.36, No.9, (September 1998), pp. 474-477.

Chun, HS., Gibson, GE., DeGiorgio, LA., Zhang, H., Kidd, VJ., \& Son, JH. (2001). Dopaminergic cell death induced by $\mathrm{MPP}(+)$, oxidant and specific neurotoxicants shares the common molecular mechanism. Journal of Neurochemisty. Vol.76, Vo.4, (February 2001), pp. 1010-1021. 
Cicchetti, F., Lapointe, N., Roberge-Tremblay, A., Saint-Pierre, M., Jimenez, L., Ficke, B.W., \& Gross, RE. (2005). Systemic exposure to paraquat and maneb models early Parkinson's disease in young adult rats. Neurobiology of Disease. Vol.20, No2, (November 2005), pp. 360-371.

Coban, A., \& Filipov, NM. (2007). Dopaminergic toxicity associated with oral exposure to the herbicide atrazine in juvenile male C57BL/6 mice. Journal of Neurochemistry. Vol.100, No.5, (March 2007), pp. 1177-1187.

Cole, LM., \& Casida, JE. (1986). Polychlorocycloalkane insecticide-induced convulsions in mice in relation to disruption of the GABA-regulated chloride ionophore. Life Sciences. Vol.39, No.20, (November 1986), pp. 1855-1862.

Conning, DM., Fletcher, K., \& Swann, ABB. (1969). Paraquat and related bipyridyls. British Medical Bulletin. Vol. 25, No. 3, pp.245-249.

Corrigan, FM., Murray, L., Wyatt, CL., \& Shore, RF. (1998). Diorthosubstituted polychlorinated biphenyls in caudate nucleus in Parkinson's disease. Experimental Neurology. Vol.150, No.2, (April 1998), pp. 339-342.

Corrigan, FM., Wienburg, CL, Shore, RF., Daniel, SE., \& Mann, D. (2000). Organochlorine insecticides in substantia nigra in Parkinson's disease. Journal of Toxicology and Environmental Health. Part A. Vol.59, No.4, (February 2000), pp. 229-234.

Cronin, S., Greenway, MJ., Prehn, JH., \& Hardiman, O. (2007). Paraoxonase promoter and intronic variants modify risk of sporadic amyotrophic lateral sclerosis. Journal of Neurology, Neurosurgery, and Psychiatry. Vol.78, No.9, (September 2007), pp. 984-986.

Curwin, BD., Hein, MJ., Sanderson, WT., Striley, C., Heederik, D., Kromhout, H., Reynolds, SJ., \& Alavanja, MC. (2007). Urinary pesticide concentrations among children, mothers and fathers living in farm and non-farm households in Iowa. The Annals of Occupational Hygiene. Vol.51, No.1, (January 2007), pp. 53-65.

Das, PC., McElroy, WK., \& Cooper, RL. (2000). Differential modulation of catecholamines by chlorotriazine herbicides in phenochromocytoma (PC12) cells in vitro. Toxicological Sciences. Vol.56, No.2, (August 2000), pp. 324-331.

Das, PC., McElroy, WK., \& Cooper, RL. (2001). Alteration of catecholamines in phenochromocytoma (PC12) cells in vitro by the metabolites of chlorotriazine herbicide. Toxicological Sciences. Vol.59, No.1, (January 2001), pp. 127-137.

Das, PC., McElroy, WK., \& Cooper, RL. (2003). Potential mechanisms responsible for chlorotriazine-induced alterations in catecholamines in phenochromocytoma (PC12) cells. Life Sciences. Vol.73, No.24, (October 2003), pp. 3123-3138.

Dodd, PR. (2002). Excited to death: different ways to lose your neurones. Biogerentology. Vol.3, No.1-2, pp. 51-56.

Domico, LM., Zeevalk, GD., Bernard, LP., \& Cooper, KR. (2006). Acute neurotoxic effects of mancozeb and maneb in mesencephalic neuronal cultures are associated with mitochondrial dysfunction. Neurotoxicology. Vol.27, No.5, (September 2006), pp. 816-825.

Ebadi, M., \& Sharma, SK. (2003). Peroxynitrite and Mitochondrial Dysfunction in the Pathogenesis of Parkinson's Disease. Antioxidant and Redox Signalling.Vol.5, No.3, (June, 2003) pp. 319-335.

Elbaz, A., Dufouil, C., \& Alpérovitch A. (2007). Interaction between genes and environment in neurodegenerative diseases. Comptes Rendus Biologies. Vol.330, No.4, (April 2007), pp. 318-328. 
EPA. (2002). Registration Eligibility Decision for Endosulfan. EPA 738-R-02-013. July 2011, Available from: http://www.epa.gov/oppsrrd1/REDs/endosulfan_red.pdf

EPA. (2003). Revised Atrazine Interim Registration Eligibility Document. EPA-HQ-OPP2003-0367-0003. August 2011, available from:

http://www.epa.gov/oppsrrd1/REDs/atrazine_combined_docs.pdf

EPA. (2005). Registration Eligibility Decision (RED) for Maneb. EPA 738-R-05-XXX. August 2011, Available from: http://www.epa.gov/oppsrrd1/REDs/maneb_red.pdf

EPA. (2010). Endosulfan: final product cancellation order. Federal Register. Vol.75, No.217.

FR Doc No: 2010-28138. EPA-HQ-OPP-2002-0262. July 2011, Available from: http://www.gpo.gov/fdsys/pkg/FR-2010-11-10/pdf/2010-28138.pdf

EPA. (2011). Pesticides Industry Sales and Usage 2006 and 2007 Market Estimates. September, 2011, Available from:

http://www.epa.gov/opp00001/pesticides/market_estimate2007.pdf

EPA Persistent Bioaccumulative and Toxic (PBT) Chemical Program. (2011). August 2011, Available from: http://www.epa.gov/pbt/pubs/aldrin.htm

Fahn, S. (1999). Parkinson disease, the effect of levodopa, and the ELLDOPA trial. Archives of Neurology. Vol.56, (May, 1999) pp. 529-535.

Fahn, S., Oakes, D., Shoulson, Ira., Kieburtz, K., Rudolph, A., Lang, A., Olanow, W., Tanner, C., \& Marek, K. (2004). Levodopa and Progression of Parkinson's disease. New England Journal of Medicine. Vol.351, (December, 2004) pp. 2498-2508.

Fei, Q., \& Ethell, DW. (2008). Maneb potentiates paraquat neurotoxicity by inducing key Bcl2 family members. Journal of Neurochemistry. Vol.105, No.6, (June 2008), pp. 20912097.

Fernagut, PO., Huston, CB., Fleming, SM., Tetreaut, NA., Salcedo, J., Masliah, E., \& Chesselet, MF. (2007). Behavioral and histopathological consequences of paraquat intoxication in mice: Effects of a-synuclein over-expression. Neuroscience. Vol.61, No.12, (September, 2007) pp. 991-1001.

Ferrante, RJ., Schluz, JB., Kowall, NW., Beal, MF. (1997). Systemic administration of rotenone produces selective damage in the striatum and globus pallidus, but not the substantia nigra. Brain Research. Vol. 752, No.1, (April, 1997) pp. 157-162.

Filipov, NM., Stewart, MA., Carr, RL., \& Sistrunk, SC. (2007). Dopaminergic toxicity of the herbicide atrazine in rat striatal slices. Toxicology. Vol.232, No.1-2, (March-April 2007), pp. 67-78.

Firestone, JA., Smith-Weller, T., Franklin, G., Swanson, P., Longstreth, WT., \& Checkoway, H. (2005). Pesticides and risk of Parkinson's disease. A population-based casecontrol study. Archives of Neurology. Vol.62 No.1, (January 2005), pp. 91-95.

Franco, R., Li, S., Rodriguez-Rocha, H., Burns, M., \& Panayiotidis, MI. (2010). Molecular mechanisms of pesticide-induced neurotoxicity: Relevance to Parkinson's disease. Chemico-Biological Interactions. Vol.188, No.2, (November 2010), pp. 289-300.

Gammon, DW., Aldous, CN., Carr, WC Jr., Sanborn, JR., \& Pfeifer, KF. (2005). A risk assessment of atrazine use in California: human health and ecological aspects. Pest Management Science. Vol.61, No.4, (April 2005), pp. 331-355.

Gatto, NM., Cockburn, M., Bronstein, J., Manthripragada, AD., \& Ritz, M. (2009). Well-water consumption and Parkinson's Disease in rural California. Environmental Health Perspective. Vol.117, No.12, (December, 2009) pp. 1912-1918. 
Gauthier, E., Fortier, I., Couchesne, F., Pepin, P., Mortermer, J., \& Gauvreau, D. (2001). Environmental pesticide exposure as a risk factor for Alzheimer's disease: a casecontrol study. Environmental Research. Vol.86, No.1, (May 2001), pp. 37-45.

Giusi, G., Facciolo, RM., Canonaco, M., Alleva, E., Belloni, V., Dessi-Fulgheri, F., \& Santucci, D. (2006). The endocrine disruptor atrazine accounts for a dimorphic somatostatinergic neuronal expression pattern in mice. Toxicological Sciences. Vol.89, No.1, (January 2006), pp. 257-264.

Gorell, JM., Johnson, CC., Rybicki, BA., Peterson, EL., \& Richardson, RJ. (1998). The risk of Parkinson's disease with exposure to pesticides, farming, well water, and rural living. Neurology. Vol.50, No.5, (May 1998), pp. 1346-1350.

Government of Canada (2009). Endosulfan: Canada's submission of information specified in Annex E of the Stockholm Convention pursuant to Article 8 of the Convention. July 2011, Available from:

http://chm.pops.int/Portals/0/docs/Responses_on_Annex_E_information_for_e ndosulfan/Canada_090110_SubmissionEndosulfanInformation.doc

Gysin, H., \& Knuesli, E. (1960). Chemistry and herbicidal properties of triazine derivatives. In: Advances in Pest Control Research, R. Metcalf (Ed.), pp. 289-358, ISSN 0568-0107, Interscience, New York, USA.

Hatcher, JM., Richardson, JR., Guillot, TS., McCormack, AL., Di Monte, DA., Jones, DP., Pennell, KD., \& Miller, GW. (2007). Dieldrin exposure induces oxidative damage in the mouse nigrostriatal dopamine system. Experimental Neurology. Vol.204, No.2, (April 2007), pp. 619-630.

Hatefi, Y. (1985). The Mitochondrial Electron Transport and Oxidative Phosphorylation System. Annual Review of Biochemistry. Vol.54, (July, 1985) pp. 1015-1069.

Hayden, KM., Northon, MC., Darcey, D., Ostbye, T., Zandi, PP., Breitner, JC., WelshBohmer, KA.; \& Cache County Study Investigators. (2010). Occupational exposure to pesticides increases the risk of incident AD: the Cache County Study. Neurology. Vol.74, No.19, (May 2010), pp. 1524-1530.

Hayes, WJ., \& Laws, ER. (1991). Handbook of pesticide toxicology. Academic Press, ISBN 0123341604, San Diego, USA, pp. 816-822.

Hazardous Substances Databank. (1995). Paraquat. March, 1994. Available from: http:/ / toxnet.nlm.nih.gov/cgi-bin/sis/search/f?./temp/ 1ob7B1:1

Health Canada (2011). Discontinuation of Endosulfan. ISSN: 1925-0649; 1925-0630.

Heikkila, RE., Manzino, L., Cabbat, FS., Duvoisin, RC. (1984). Protection against the dopaminergic neurotoxicity of 1-methyl-4-phenyl-1,2,5,6-tetrahydropyridine by monoamine oxidase inhibitors. Letters to Nature. Vol. 311, (October, 1984) pp.467469.

Hertzman, C., Wiens, M., Bowering, D., Snow, B., \& Calne, D. (1990). Parkinson's disease: a case-control study of occupational and environmental risk factors. American Journal of Industrial Medicine. Vol.17, No.3, pp. 349-355.

Hertzman, C., Wiens, M., Snow, B., Kelly, S., \& Calne, D. (1994). A case control study of Parkinson's disease in a horticultural region of British Columbia. Movement Disorders. Vol.9, No.1, (January 1994), pp. 69-75.

Hincal, F., Gürbay, A., \& Giray, B. (1995). Induction of lipid peroxidation and alteration of glutathione redox status by endosulfan. Biological Trace Element Research. Vol.47, No.1-3, (January-March), pp. 321-326. 
Hoglinger, GU., Lannuzel, A., Khondiker, ME, Michel, PP., Duyckaerts, C., Feger, J., Champy, P., Prigent, A., Medja, F., Lombes, A., Oertel, WH.,Ruberg, M., \& Hirsch, EC. (2005). The mitochondrial cerebral inhibitor rotenone triggers a cerebral taupathy. Journal of Neurochemistry. Vol.95, No.4, (October, 2005) pp.930-939.

Hong, JS., Herr, DW., Hudson, PM., \& Tilson, HA. (1986). Neurochemical effects of DDT in rat brain in vivo. Archives of Toxicology. Supplement. Vol.9, pp. 14-26.

Hossain, MM., \& Filipov, NM. (2008). Alteration of dopamine uptake into rat striatal vesicles and synaptosomes caused by an in vitro exposure to atrazine and some of its metabolites. Toxicology. Vol.248, No.1, (June 2008), pp. 52-58.

Ikeda, T., Nagata, K., Shono, T., \& Narahashi, T. (1998). Dieldrin and picrotoxinin modulation of GABA(A) receptor single channels. Neuroreport. Vol.9, No.14, (October 1998), pp. 3189-3195.

Inden, M., Kitamura, Y., Abe, M., Tamaki, A., Takata, K., \& Taniguchi, T. (2010). Parkinsonian Rotenone Mouse Model: Re-evaluation of Long-Term Administration of Rotenone in C57BL/6 Mice. Biological and Pharmaceutical Bulletin. Vol.34, No.1, (October, 2010).

Jia, Z., \& Misra, HP. (2007). Developmental exposure to pesticides zineb and/or endosulfan renders the nigrostriatal dopamine system more susceptible to these environmental chemicals later in life. Neurotoxicology. Vol.28, No.4, (July), pp. 727-735.

Kachroo, A., Irizarry, MC., \& Schwarzschild, MA. (2010). Caffeine protects against combined paraquat and maneb-induced dopaminergic neuron degeneration. Experimental Neurology. Vol.223, No.2, (June 2010), pp. 657-661.

Kang, K., Park, J., Ryu, D., \& Lee, Y. (2001). Effects and neuro-toxic mechanisms of 2, 2', 4, 4', 5, 5'-hexachlorobiphenyl and endosulfan in neuronal stem cells. Journal of Veterinary Medical Science. Vol.63, No.11, (November 1991), pp. 1183-1190.

Kanthasamy, AG., Kitazawa, M., Kanthasamy, A., \& Anantharam, V. (2005). Dieldrininduced neurotoxicity: relevance to Parkinson's disease pathogenesis. Neurotoxicology. Vol.26, No.4, (August 2005), pp. 701-719.

Karatas, AD., Aygun, D., \& Baydin, A. (2006). Characteristics of endosulfan poisoning: a case study of 23 cases. Singapore Medical Journal. Vol.47, No.12, (December 2006), pp. 1030-1032.

Kiely, T., Donaldson, D., \& Grube, A. (2004). Pesticides Industry Sales and Useage. 2000 and 2001 Market Estimates. US EPA. July 2011, Available from: http://www.epa.gov/opp00001/pestsales/01pestsales/ market_estimates2001.pdf

Kim, YH., Rane, A., Lussier, S., \& Andersen, JK. (2011). Lithium protects against oxidativestress-mediated cell death in a a-synuclein-overexpressing in vitro and in vivo models of Parkinson's disease. Journal of Neuroscience Research. Vol.89, No.10, (October 2011), pp. 1666-1675.

Kitazawa, M., Anantharam, V., \& Kanthasamy, AG. (2001). Dieldrin-induced oxidative stress and neurochemical changes contribute to apoptopic cell death in dopaminergic cells. Free Radical Biology and Medicine. Vol.31, No.11, (December 2001), pp. 1473-1485.

Klaassen, CD., (Ed). (1996). Casarett $\mathcal{E}$ Doull's toxicology: the basic science of poisons. $5^{\text {th }}$ ed. MacGraw-Hill Publishing Company. ISBN 0071470514, New York, USA, pp. 542547. 
Koller, W., Vetere-Overfield, B., Gray, C., Alexander, C., Chin, T., Dolezal, J, Hassanein, R., \& Tanner, C. (1990). Environmental risk factors in Parkinson's disease. Neurology. Vol.40, No.8, (August 1990), pp. 1218-1221.

Kuopio, A-M., Marttila, RJ., Helenius, H., \& Rinne, UK. (1999). Environmental risk factors in Parkinson's disease. Movement Disorders. Vol.14, No.6, (November 1999), pp. 928 939.

Lake, C., Wormstall, H., Einsiedler, K., \& Buchkremer, G. (2004). Alzherimer's disease with secondary Parkinson's syndrome. Case report of a patient with dementia and Parkinson's syndrome after long-term occupational exposure to insecticides, herbicides, and pesticides. Der Nervenarzt. Vol.75, No.11, (November 2004), pp. 1107-1111.

Lakshmana, MK., \& Raju, TR. (1994). Endosulfan induces small but significant changes in the levels of noradrenaline, dopamine and serotonin in the developing rat brain and deficits in the operant learning performance. Toxicology. Vol.91, No.2, (July 1994), pp. 139-50.

Landers, JE., Shi, L., Cho, TJ., Glass, JD., Shaw, CE., Leigh, PN., Diekstra, F., Polak, M., Rodriguez-Leyva, I., Niemann, S., Traynor, BJ., McKenna-Yasek, D., Sapp, PC., AlChalabi, A., Wills, AM., \& Brown, RH Jr. (2008). A common haplotype within the PON1 promoter region is associated with sporadic ALS. Amyotrophic Lateral Sclerosis. Vo.9, No.5, (October 2008), pp. 306-314.

Langston, JW., Ballard, P., Tetrud, JW., \& Irwin, I. (1993). Chronic Parkinsonism in humans due to a product of meperidine-analog synthesis. Science. Vol.219, No.4587, (February 1993) pp. 979-980.

Lee, E., Burnett, CA., Lalich, N., Cameron, LL., \& Sestito, JP. (2002). Proportionate mortality of crop and livestock farmers in the United States, 1984-1993. American Journal of Industrial Medicine. Vol.42, No.5, (November 2002), pp. 410-20.

Lesnick, TG., Papapetropoulos, S., Mash, DC., Ffrench-Mullen, J., Shehadeh, L., Andrade, M., Henley, JR., Rocca, WA., Ahlskog, JE., \& Maraganore, DM. (2007). A Genomic Pathway Approach to a Complex Disease: Axon Guidance and Parkinson Disease. PLoS Genetics. Vol.3, No.6, (June, 2007).

Li, X., Matsumoto, K., Murakami, Y., Tezuka, Y., Wu, Y., \& Kadota, S. (2005). Neuroprotective effects of Polygonum multiflorum on nigrostriatal dopaminergic degeneration induced by paraquat and maneb in mice. Pharmacology, Biochemistry and Behavior. Vol.82, No.2, (October 2005), pp. 345-352.

Liou, HH., Tsai, MC., Chen, CJ., Jeng, JS., Chang, YC., Chen, SY., \& Chen, RC. (1997). Environmental risk factors and Parkinson's disease: a case-control study in Taiwan. Neurology. Vol.48, No.6, (June 1997), pp. 1583-1588.

Manning-Bog, A.M., McCormack, AL., Li, J., Uversky, VN., Fink, AL., \& Di Monte, DA. (2003). The Herbicide Paraquat Causes Up-Regulation and Aggregation of asynuclein in Mice. The Journal of Biological Chemistry. Vol.277, (January, 2002) pp.1641-1644.

Matile, Ph., \& Moor. (1967). Vacuolation: Origin and the development of the lysosomal apparatus in root tip cells. Planta. Vol.80, No.2, pp. 159-175.

McGuire, V., Longstreth, WT Jr., Nelson, LM., Koepsell, TD., Checkoway, H., Morgan, MS., \& van Belle, G. (1997). Occupational exposures and amyotrophic lateral sclerosis. A population-based case-control study. American Journal of Epidemiology. Vol.145, No.12, (June 1997), pp. 1076-1088. 
McNaught, KS., Olanow, CW., Halliwell, B., Isacson, O., \& Jenner, P. (2001). Failure of the ubiquitin-proteasome system in Parkinson's disease. Nature Reviews. Neuroscience. Vol.2, No.8, (August 2001), pp. 589-594.

Michaelis, L., \& Hill, ES. (1933). Potentiometric Studies on Semiquinones. Journal of American Chemical Society. Vol.55, No.4, (April 1933) pp. 1481-1494.

Moon, JM., \& Chun, BJ. (2009). Acute endosulfan poisoning: a retrospective study. Human and Experimental Toxicology. Vol.28, No.5, (May 2009), pp. 309-316.

Morahan, JM., Pamphlett, R. (2006). Amyotrophic lateral sclerosis and exposure to environmental toxins: an Australian case-control study. Neuroepidemiology. Vol.27, No.3, pp. 130-135.

Occupational Health Services, Inc. (1991). MSDS for Maneb. OHS Inc., Secaucus, NJ, USA.

Obeso, JA., Olanow, CW., Nutt, JG. (2000). Levodopa motor complications in Parkinson's disease. Trends in Neurscience. Vol. 23, No. 1, (October, 2000) pp. S2-S7

Ossowska, K., Wardas, J., Smiatowska, M., Kuter, K., Lenda, T., Wieronska, JM., Zieba, B., Nowak, P., Dabrowska, J., Bortel, A., Kwiecinski, A., \& Wolfarth, S. (2005). A slowly developing dysfunction of dopaminergic nigrostriatal neurons induced by long-term paraquat administration in rats: an animal model of preclinical stages of Parkinson's disease? Neuroscience. Vol.22, No.6, (September, 2005) pp. 1294-1304.

Pan, T., Rawal, P., Wu, Y., Xie, W., Jankovic, J., \& Le, W. (2009). Rapamycin protects against rotenone-induced apoptosis through autophagy induction. Neuroscience. Vol.164, No.2, (December, 2009) pp. 541-551

Park, RM., Schulte, PA., Bowman, JD., Walker, JT., Bondy, SC., Yost, MG., Touchstone, JA., \& Dosemeci, M. (2005). Potential occupational risks for neurodegenerative diseases. American Journal of Industrial Medicine. Vol.48, No.1, (July 2005), pp. 63-77.

Parrón, T., Requena, M., Hernández, AF., \& Alarcón, R. (2011). Association between environmental exposure to pesticides and neurodegenerative diseases. Toxicology and Applied Pharmacology. (May 2011), Doi: 10.1016/j.taap.2011.05.006.

Paul, V., Balasubramaniam, E., \& Kazi, M. (1994). The neurobehavioural toxicity of endosulfan in rats: a serotonergic involvement in learning impairment. European Journal of Pharmacology. Vol.270, No.1, (January 1994), pp. 1-7.

Peterson, RT., Nass, R., Boyd, WA., Freedman, JH., Dong, K., \& Narahashi, T. (2008). Use of non-mammalian alternative models for neurotoxicological study. Neurotoxicology. Vol.29, No.3, (May 2008), pp. 546-555.

Pradhan, S., Pandey, N., Phadke, RV., Kaur, A., Sharma, K., \& Gupta, RK. (1997). Selective involvement of basal ganglia and occipital cortex in a patient with acute endosulfan poisoning. Journal of Neurological Sciences. Vol.47, No.2, (April 1997), pp. 201-213.

Priyadarshi, A., Khuder, SA., Schaub, EA., \& Priyadarshi, SS. (2001). Environmental risk factors and Parkinson's disease: a metaanalysis. Environmental Research. Vol.86, No.2, (June 2001), pp. 122-127.

Priyadarshi, A., Khuder, SA., Schaub, EA., Shrivastava, S. (2000). A meta-analysis of Parkinson's disease and exposure to pesticies. Neurotoxicology. Vol.21, No.4, (August 2000), pp. 435-440.

Quijano, RF. (2002). Endosulfan poisoning in Kasargod, Kerala, India. Report of a fact finding mission. Pesticide Action Network Asia and the Pacific. July 2011, Available at

http://www.panap.net/sites/default/ files/endosulfan_report_Kerala_1.pdf 
Qureshi, MM., Hayden, D., Urbinelli, L., Ferrante, K., Newhall, K., Myers, D., Hilgenberg, S., Smart, R., Brown, RH., \& Cudkowicz, ME. (2006). Analysis of factors that modify susceptibility and rate of progression in amyotrophic lateral sclerosis (ALS). Amyotrophic Lateral Sclerosis. Vol.7, No.3, (September 2006), pp. 173-182.

Ribaudo, MO., \& Bouzaher, A. (1994). Atrazine: Environmental Characteristics and Economics of Management. United States Department of Agriculture. Agricultural Economic Report Number 699. July 2011, Available at http://www.ers.usda.gov/publications/AboutPDF.htm

Richardson, JR., Caudle, WM., Wang, M., Dean, ED., Pennell, KD., \& Miller, GW. (2006). Developmental exposure to the pesticide dieldrin alters the dopamine system and increases neurotoxicity in an animal model of Parkinson's disease. The FASEB Journal. Vol.20, No.10, (August 2006), pp. 1695-1697.

Rocca, WA., Bonaiuto, S., Lippi, A., Luciani, P., Turtù, F., Cavarzeran, F., \& Amaducci, L. (1990). Prevalence of clinically diagnosed Alzheimer's disease and other dementing disorders: A door-to-door survey in Appignano, Macerata Province, Italy. Neurology. Vol.40, No.4, (April 1990), pp. 626-663.

Rodríguez-Navarro, J., Rodríguez, L., Casarejos, MJ., Solano, RM., Gómez, A., Perucho, J., Cuervo, AM., de Yébenes, JG., \& Mena, MA. (2010). Trehalose ameliorates dopaminergic and tau pathology in parkin deleted/tau overexpressing mice through autophagy activation. Neurobiology of Diseases. Vol.39, No. 3, (September, 2010) pp. 423-438.

Rodríguez, VM., Thiruchelvam, M., \& Cory-Slechta, DA. (2005). Sustained exposure to the widely used herbicide atrazine: altered function and loss of neurons in brain monoamine systems. Environmental Health Perspectives. Vol.113, No.6, (June 2005), pp. 708-715.

Roede, J.R., Hansen, J.M., Go, Y.M., \& Jones, D.P. (2011). Maneb and paraquat-mediated neurotoxicity: involvement of peroxiredoxin/thioredoxin system. Toxicological Sciences. Vol.121 No.2, (June), pp. 368-375.

Ross, MK., Jones, TL., \& Filipov, NM. (2009). Disposition of the herbicide 2-chloro-4(ethylamino)-6-(isopropylamino)-s-triazine (Atrazine) and its major metabolites in mice: a liquid chromatography/mass spectrometry analysis of urine, plasma, and tissue levels. Drug Metabolism and Disposition: the Biological Fate of Chemicals. Vol.37, No.4, (April 2009), pp. 776-786.

Saeed, M., Siddique, N., Hung, WY., Usacheva, E., Liu, E., Sufit, RL., Heller, SL., Haines, JL., Pericak-Vance, M., \& Siddique, T. (2006). Paraoxonase cluster polymorphisms are associated with sporadic ALS. Neurology. Vol.67, No.5, (September 2006), pp. 771776.

Sanchez-Ramos, J., Facca, A., Basit, A., \& Song, S. (1998). Toxicity of dieldrin for dopaminergic neurons. Experimental Neurology. Vol.150, No.2, (April 1998), pp. 263271.

Sano, M., Ernesto, C., Thomas, RG., Klauber, MR., Schafer, K., Grundman, M., Woodbury, P., Growdon, J., Cotman, CW., Pfeiffer, E., Schneider, LS., \& Thal, LJ. (1997). A controlled trial of selegiline, alpha-tocopherol, or both as treatment for Alzheimer's disease. The Alzheimer's Disease Cooperative Study. New England Journal of Medicine. Vol.336, No.17, (April, 1997) pp. 1216-1222.

Seidler, A., Hellenbrand, W., Robra, B-P., Vieregge, P., Nischan, P., Joerg, J., Oertel, WH., Ulm, G., \& Schneider, E. (1996). Possible environmental, occupational, and other 
etiologic factors for Parkinson's disease: a case-control study in Germany. Neurology. Vol.46, No.5, (May 1996), pp. 1275-1284.

Semchuk, KM., Love, EJ., \& Lee, RG. (1992). Parkinson's disease and exposure to agricultural work and pesticide chemicals. Neurology. Vol.42, No.7, (July 1992), pp. $1328-1335$.

Silva, MH., \& Gammon, D. (2009). An assessment of the developmental, reproductive and neurotoxicity of endosulfan. Birth Defects Research (Part B). Vol.86, No.1, (February 2009), pp. 1-28.

Singh, ND., Sharma, AK., Dwivedi, P., Patil, RD., \& Kumar, M. (2007). Citrinin and endosulfan induced maternal toxicity in pregnant Wistar rats: pathomorphological study. Journal of Applied Toxicology. Vol.27, No.6, (November-December), pp. 589601.

Singhal, NK., Srivastava, G., Patel, DK., Jain, SK., \& Singh, MP. (2011). Melatonin or silymarin reduces maneb- and paraquat-induced Parkinson's disease phenotype in the mouse. Jounal of Pineal Research. Vol.50, No.2, (March 2011), pp. 97-109.

Sirivarasai, J., Kaojarern, S., Yoovathaworn, K., \& Sura, T. (2007). Paraoxonase (PON1) polymorphism and activity as the determinants of sensitivity to the organophosphates in human subjects. Chemico-Biolical Interact. Vol.168, No.3, (July), pp. 184-192.

Sivaraman, Valsala, Indulal, Gangadharan, Kalavathy, Beegom. (2003). Healh hazards of aerial spraying of endosulfan in Kasargod district, Kerala. Government of Kerala. July 2011, Available from: http://endosulphanvictims.org/resources/KeralaGovt_FinalReport.pdf

Slowik, A., Tomik, B., Wolkow, PP., Partyka, D., Turaj, W., Malecki, MT., Pera, J., Dziedzic, T., Szczudlik, A., \& Figlewicz, DA. (2006). Paraoxonase gene polymorphism and sporadic ALS. Neurology. Vol.67, No.5, (September 2006), pp. 766-770.

Smith, P., \& Heath, D. (1976). Paraquat. Critical Reviews in Toxicology. Vol.4, No.4, (October, 1976) pp. 411-445.

Soderlund, DM., \& Bloomquist, JR. (1989). Neurotoxic actions of pyrethroid insecticides. Annual Review of Entomology. Vol.34, pp. 77-96.

Somayajulu-Nițu, M., Sandhu, JK., Cohen, J., Sikorska, M., Sridhar, TS., Matei, A., Borowy Borowski, H \& Pandey, S. (2009). Paraquat induces oxidative stress, neuronal loss in substantia nigra region and Parkinsonism in adult rats: Neuroprotection and amelioration of symptoms by water-soluble formulation of Coenzyme Q10. BMC Journal of Neuroscience. Vol.10, No.88, (July 2009).

Sohal, RS., \& Weindruch, R. (1996). Oxidative Stress, Caloric Restriction and Ageing. Science. Vol.273, No.5271, (July, 1995) pp. 59-63.

Stevens, JT., \& Sumner, D D. (1991). Herbicides. In Handbook of Pesticide Toxicology. Academic Press, New York.Vol. 3, pp. 1317-1408.

Storch, A., Ludolph, AC., \& Schwarz, J. (2004). Dopamine transporter: involvement in selective dopaminergic neurotoxicity and degeneration. Journal of Neural Transmission. Vol.111, No.10-11, (October 2004), pp. 1267-1286.

Sulkava, R., Heliovaara, M., Palo, J., Wikstrom, J., \& Aromaa, A. (1988). Regional differences in the prevalence of Alzheimer's disease, In Soininen H (Ed): Proceedings of the International Symposium on Alzheimer's disease. ISBN 9517804881, Kuopio, Finland, University of Kuopio, June 12-15, 1988. 
Takahashi, RN., Rogerio, R., \& Zanin, M. (1989). Maneb enhances MPTP neurotoxicity in mice. Research Communications in Chemical Pathology and Pharmacology. Vol.66, No.1, (October 1989), pp. 167-70.

The Parkinson's Study Group. Effects of Tocopherol and Deprenyl on the Progression of Disability in Early Parkinson's Disease. (1993). The New England Journal of Medicine.Vol. 328. (January, 1994). Pp. 176-183.

Thiffault, C., Langston, WJ., Di Monte, DA. (2001). Acute exposure to organochlorine pesticides does not affect striatal dopamine in mice. Neurotoxicology Research. Vol.3, No.6, (November 2001), pp. 537-543.

Thiruchelvam, M., Brockel, BJ., Richfield, EK., Baggs, RB. \& Cory-Slechta, DA. (2000a). Potentiated and preferential effects of combined paraquat and maneb on nigrostriatal dopamine systems: environmental risk factors for Parkinson's disease? Brain Research. Vol.873, No.2, (August 2000), pp. 225-234.

Thiruchelvam, M., Richfield, E.K., Baggs, R.B., Tank, A.W. \& Cory-Slechta, DA. (2000b). The nigrostriatal dopaminergic system as a preferential target of repeated exposures to combined paraquat and maneb: implications for Parkinson's disease. Journal of Neurosciences. Vol.20, No.24, (December 2000), pp. 9207-9214.

Thiruchelvam, M., Richfield, EK., Goodman, BM., Baggs, RB., \& Cory-Slechta, DA. (2002). Developmental exposure to the pesticides paraquat and maneb and the Parkinson's disease phenotype. Neurotoxicology. Vol.23, No.4-5, (October, 2002), pp. 321-333.

Thiruchelvam, M., Richfield, EK., Goodman, BM., Baggs, RB., \& Cory-Slechta, DA. (2005). Developmental exposure to the pesticides paraquat and maneb and the Parkinson's disease phenotype. Neurotoxicology. Vol.23, No.4-5, (October 2005), pp. 621-633.

Tomita, M., Okuyama, T., Katsuyama, H., Miura, Y., Nishimura, Y., Hidaka, K., Otsuki, T., \& Ikawa, TI. (2007). Mouse model or paraquat-poisoned lungs and its gene expression profile. Toxicology. Vol.231, No.2-3, (March, 2007) pp. 200-209.

Tsai, CH., Lo, SK., See, LC., Chen, HZ., Chen, RS., Weng, YH., Chang, FC., \& Lu, CS. (2002). Environmental risk factors of young onset Parkinson's disease: a case-control study. Clinical Neurology and Neurosurgery. Vol.104, No.4, (September 2002), pp. 328333.

Tuchsen, F., \& Jensen, AA. (2000). Agricultural work and the risk of Parkinson's disease in Denmark, 1981-1993. Scandinavian Journal of Work, Environment and Health. Vol.26, No.4, (August 2000), pp. 359-362.

Uversky, VN. (2004). Neurotoxicant- induced animal models of Parkinson's disease: understanding the role of rotenone, maneb and paraquat in neurodegeneration. Cell and Tissue Research. Vol.318, No.1 (October, 2004) pp. 225-251.

Valdmanis PN, Kabashi E, Dyck A, Hince P, Lee J, Dion P, D'Amour M, Souchon F, Bouchard JP, Salachas F, Meininger V, Andersen PM, Camu W, Dupré N, Rouleau GA. (2008). Association of paraoxonase gene cluster polymorphisms with ALS in France, Quebec, and Sweden. Neurology. 71(7):514-520.

Wagner, SL. (1981). Clinical Toxicology of Agricultural Chemicals. Environmental Health Science. pp. 309.

Walsh, TJ., \& Chrobak, JJ. (1987). The use of the radial arm maze in neurotoxicology. Physiology and Behavior. Vol.40, No.6, pp. 799-803.

Weed Science Society of America, 1994.

Weisskopf, MG., Morozova, N., O'Reilly, EJ., McCullough, ML., Calle, EE., Thun, MJ., \& Ascherio, A. (2009). Prospective study of chemical exposures and amyotrophic 
lateral sclerosis. Journal of Neurology, Neurosurgery and Psychiatry. Vol.80, No.5, (May 2009), pp. 558-561.

Weisskopf, MG., Knekt, P., O'Reilly, EJ., Lyytinen, J., Reunanen, A., Kaden, F., Altshul, L., \& Ascherio, A. (2010). Persistent organochlorine pesticides in serum and risk of Parkinson disease. Neurology. Vol.74, No.13, (mo), pp. 1055-1061.

Wesseling, C., Joode, WD., Rupert, C., Leon, C., Monge, P., Hermosillo, H., \& Partnen, T J. (2001). Paraquat in Developing Countries. International Journal of Occupational Environmental Health. Vol.7, No.4, (October, 2001) pp. 275-286

Wills, AM., Cronin, S., Slowik, A., Kasperaviciute, D., Van Es, MA., Morahan, JM., Valdmanis, PN., Meininger, V., Melki, J., Shaw, CE., Rouleau, GA., Fisher, EM., Shaw, PJ., Morrison, KE., Pamphlett, R., Van den Berg, LH., Figlewicz, DA., Andersen, PM., Al-Chalabi, A., Hardiman, O., Purcell, S., Landers, JE., \& Brown, RH Jr. (2009). A large-scale international meta-analysis of paraoxonase gene polymorphisms in sporadic ALS. Neurology. Vol.73, No.1, (July 2009), pp. 16-24.

Wirdefeldt, K., Adami, HO., Cole, P., Trichopoulos, D., \& Mandel, J. (2011). Epidemiology and etiology of Parkinson's disease: a review of the evidence. European Journal of Epidemiol. Suppl 1 (June 2011), pp. S1-58.

www2.syngenta.com/en/about_syngenta/companyhistory.html

www.zymes.com

Xu, HY., Chen, RR., Cai, XY., \& He, DF. (2011). Effects of co-exposure to paraquat and maneb on system of substantia nigra and striatum in rats. Zhonghua Lao Dong Wei Sheng Zhi Ye Bing Za Zhi. Vol.29, No1, (January 2011), pp. 33-38.

Yang, X., Jiang, Y., Weng, J., Wang, J. (2004). Study on the influence on the proliferation and the induction of apoptosis on PC 12 cells by endosulfan. Chinese Journal of Clinical Neurosciences. 2004-1.

Zaidi, NF., Agrawal, AK., Anand, M., \& Seth, PK. (1985). Neonatal endosulfan neurotoxicity: behavioral and biochemical changes in rat pups. Neurobehavioral Toxicology and Teratology. Vol.7, No.5, (September-October 1985), pp. 439-442.

Zhang, J., Fitsanakis, VA., Gu, G., Jing, D., Ao, M., Amarnath, V., \& Montine, TJ. (2003). Manganese ethylene-bis-dithiocarbamate and selective dopaminergic neurodegeneration in rat: a link through mitochondrial dysfunction. Journal of Neurochemistry. Vol.84, No.2, (January 2003), pp. 336-346.

Zhou, Y., Shie, FS., Piccardo, P., Montine, TJ., \& Zhang, J. (2004). Proteasomal inhibition induced by manganese ethylene-bis-dithiocarbamate: relevance to Parkinson's disease. Neuroscience. Vol.128, No.2, pp. 281-91. 


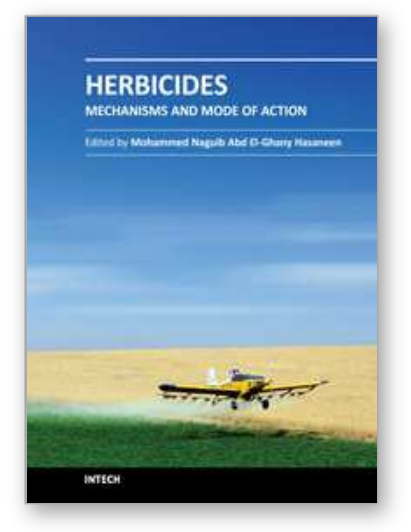

\author{
Herbicides - Mechanisms and Mode of Action \\ Edited by Dr. Mohammed Nagib Hasaneen
}

ISBN 978-953-307-744-4

Hard cover, 204 pages

Publisher InTech

Published online 22, December, 2011

Published in print edition December, 2011

This volume contains two sections: Mechanisms of herbicidal action (chapters 1-4) and Mode of action of selected herbicides on controlling diseased, weed growth and productivity and/or growth and development of field crops (chapters 5-10). Topics by chapters are: molecular mechanism of action, immunosensors , laboratory studies, molecular modeling, weed resistance, community response, use of herbicides in biotech culture, gene flow, herbicides and risk, herbicides persistence. These recurring themes reinforce my view, held over a very long time, that experience with one crop or problem can sometimes be relevant, often to an unexpected extent, to an apparently dissimilar situation in a different crop. I hope that readers interested in herbicides and pesticides will be satisfied with all the chapters in the book as its content might be of interest and value to them in the future.

\title{
How to reference
}

In order to correctly reference this scholarly work, feel free to copy and paste the following:

Krithika Muthukumaran, Alyson J. Laframboise and Siyaram Pandey (2011). Herbicides and the Risk of Neurodegenerative Disease, Herbicides - Mechanisms and Mode of Action, Dr. Mohammed Nagib Hasaneen (Ed.), ISBN: 978-953-307-744-4, InTech, Available from: http://www.intechopen.com/books/herbicidesmechanisms-and-mode-of-action/herbicides-and-the-risk-of-neurodegenerative-disease

\section{INTECH}

open science | open minds

\author{
InTech Europe \\ University Campus STeP Ri \\ Slavka Krautzeka 83/A \\ 51000 Rijeka, Croatia \\ Phone: +385 (51) 770447 \\ Fax: +385 (51) 686166 \\ www.intechopen.com
}

\author{
InTech China \\ Unit 405, Office Block, Hotel Equatorial Shanghai \\ No.65, Yan An Road (West), Shanghai, 200040, China \\ 中国上海市延安西路65号上海国际贵都大饭店办公楼405单元 \\ Phone: +86-21-62489820 \\ Fax: +86-21-62489821
}


(C) 2011 The Author(s). Licensee IntechOpen. This is an open access article distributed under the terms of the Creative Commons Attribution 3.0 License, which permits unrestricted use, distribution, and reproduction in any medium, provided the original work is properly cited. 